\title{
Astrogliopathy in Tauopathies
}

\author{
Isidro Ferrer $1,2,3,4$ (D) \\ 1 Department of Pathology and Experimental Therapeutics, University of Barcelona, Feixa Llarga sn, \\ 08907 Hospitalet de Llobregat, Spain; 8082ifa@gmail.com \\ 2 IDIBELL (Bellvitge Biomedical Research Centre), Bellvitge University Hospital, 08907 Hospitalet de \\ Llobregat, Spain; Tel.: +34-93-403-5808 \\ 3 CIBERNED (Network Centre of Biomedical Research of Neurodegenerative Diseases), Institute of Health \\ Carlos III, Ministry of Economy, Industry and Competitiveness, 08907 Hospitalet de Llobregat, Spain \\ 4 Institute of Neurosciences, University of Barcelona, 08907 Hospitalet de Llobregat, Spain
}

Received: 24 June 2018; Accepted: 29 June 2018; Published: 4 July 2018

\begin{abstract}
Astrocytes are involved in many diseases of the central nervous system, not only as reactive cells to neuronal damage but also as primary actors in the pathological process. Astrogliopathy is a term used to designate the involvement of astrocytes as key elements in the pathogenesis and pathology of diseases and injuries of the central nervous system. Astrocytopathy is utilized to name non-reactive astrogliosis covering hypertrophy, atrophy and astroglial degeneration with loss of function in astrocytes and pathological remodeling, as well as senescent changes. Astrogliopathy and astrocytopathy are hallmarks of tauopathies-neurodegenerative diseases with abnormal hyper-phosphorylated tau aggregates in neurons and glial cells. The involvement of astrocytes covers different disease-specific types such as tufted astrocytes, astrocytic plaques, thorn-shaped astrocytes, granular/fuzzy astrocytes, ramified astrocytes and astrocytes with globular inclusions, as well as others which are unnamed but not uncommon in familial frontotemporal degeneration linked to mutations in the tau gene. Knowledge of molecular differences among tau-containing astrocytes is only beginning, and their distinct functional implications remain rather poorly understood. However, tau-containing astrocytes in certain conditions have deleterious effects on neuronal function and nervous system integrity. Moreover, recent studies have shown that tau-containing astrocytes obtained from human brain tauopathies have a capacity for abnormal tau seeding and spreading in wild type mice. Inclusive conceptions include a complex scenario involving neurons, glial cells and local environmental factors that potentiate each other and promote disease progression in tauopathies.
\end{abstract}

Keywords: astrocytes; tau; seeding; spreading; tauopathies; progressive supranuclear palsy; corticobasal degeneration; Pick's disease; aging-related tau astrogliopathy; primary age-related tauopathy; frontotemporal degeneration-tau; astrocytopathy

\section{Introduction}

Tauopathies are adult-age clinically, biochemically and anatomically heterogeneous neurodegenerative diseases, defined by the depositing of excessively phosphorylated tau protein, which is abnormally folded and eventually forms aggregates in nerve cells. Tau deposits in nerve cells form neurofibrillary tangles (NFT, neurofibrillary degeneration) and pre-tangle deposits, aggregates in neuronal and glial cell processes form neuropil threads, inclusions in astrocytes give rise to different morphological types, and inclusions in oligodendrocytes mainly form coiled bodies and, rarely, globular inclusions. Certain regions of the brain, and certain cell populations, are vulnerable to the pathology of tau, although the mechanisms of regional vulnerability and selective cellular vulnerability in tauopathies are poorly understood. Tau proteins are encoded by the microtubule-associated protein tau gene $M A P T$, the transcription of which, by alternative splicing, produces six isoforms in the brain. Some 
tauopathies are identified as $4 \mathrm{R}$-tauopathies (4Rtau) and others as 3R-tauopathies (3Rtau) depending on the axon 10 splicing.

\section{Human Tauopathies}

The clinical and pathological phenotype of human tauopathies is, in part, determined by (a) the types of tau deposits (3Rtau or 4Rtau); (b) the specific regional and cellular vulnerability to each tauopathy; (c) the involvement of neurons and/or glial cells (astrocytes and oligodendrocytes); (d) the type of mutation in MAPT in familial tauopathy; and (e) the accompanying presence of extracellular amyloids, as in Alzheimer's disease (AD) (in which the tauopathy is associated with extracellular deposits of amyloid $\beta(A \beta)$ giving rise to $\beta$-amyloid plaques), but also in British familial dementia (FBD) and Danish familial dementia (FDD) linked to distinct mutations in BRI2 (or ITMM2B) and producing amyloids ABri and ADan, respectively. Certain families with Gerstmann-Straüssler-Scheinker syndrome (GSS) linked to mutations in PRNP (which encodes the prion protein) are associated with prionopathy and tauopathy.

The most frequent human sporadic tauopathy, in addition to sporadic $\mathrm{AD}$, are primary age-related tauopathy (PART), a neuronal 4Rtau + 3Rtau similar to AD but without the A $\beta$ component; aging-related tau astrogliopathy (ARTAG), a selective astrocyte 4Rtau; argyrophilic grain disease (AGD), a 4Rtau with predominant pre-tangles in neurons, protrusions in dendrites (grains) and inclusions in astrocytes and oligodendrocytes; Pick's disease (PiD), a 3Rtau with mainly neuronal involvement (Pick bodies) but also with tau deposits in astrocytes and oligodendrocytes; progressive supranuclear palsy (PSP) and corticobasal degeneration (CBD), both 4R-tauopathies with the involvement of neurons and oligodendrocytes, and with disease-specific tau deposits in astrocytes; and globular glial tauopathy (GGT), a 4Rtau with neuronal involvement and unique tau inclusions in astrocytes and globular tau deposits in oligodendrocytes [1-29].

The most common pure hereditary tauopathy is frontotemporal lobar degeneration linked to MAPT mutations (FTLD-tau). Clinically, FTLD-tau is manifested by frontal dementia (FTD) and parkinsonism; tau deposits are composed of 4Rtau, 3Rtau or 4Rtau + 3Rtau depending on the site of the mutation [30-34]. Globular glial tauopathy is mostly sporadic but certain tauopathies linked to MAPT mutations show variable amounts of globular inclusions in oligodendrocytes and bizarre astrocytic inclusions resembling sporadic GGT [35-38].

The most frequent combined tauopathy and amyloidopathy is familial AD linked to mutations in amyloid $\beta$ precursor protein (APP)-related genes: APP, presenilin1 (PSEN1), or presenilin 2 (PSEN2). British familial dementia, FDD and GSS with tauopathy are extremely rare [21,39-41]. Other tauopathies can be reviewed elsewhere [25].

A combination of different tauopathies is not rare in old-age individuals $[28,42,43]$. The combination of AD, AGD and ARTAG is frequent in old-age individuals. The association of PSP or CBD and ARTAG and AGD is usual.

\section{Non-Human Primate Tauopathies in Old Age}

Tauopathy also occurs in aged non-human primates. Major research is focused on AD-related changes (A $\beta$ deposits and tau deposits) in old-age animals. Interestingly, AD-like pathology is not rare in non-human primates, although there are marked species differences.

In cynomologous monkey (Macaca fascicularis), intraneuronal and oligodendroglial tau accumulation is found in the temporal cortex and hippocampus before the age of 20 years and before the presence of amyloid deposits; at advanced ages, NFTs and tau accumulate in dystrophic neurites [44]. An age-related increase of $A \beta$ deposits in the form of plaques and around blood vessels is frequent, with gender differences, in the neocortex and hippocampus of western lowland gorilla (Gorilla gorilla gorilla), housed in American zoos and aquarium-accredited facilities. Neurons stained for the tau marker Alz50 are found in the neocortex and hippocampus of gorillas at all ages. Occasional Alz50-, MC1- and AT8-immunoreactive astrocyte and oligodendrocyte coiled bodies and neuritic 
clusters are seen in the neocortex and hippocampus of the oldest gorillas [45]. Aged wild mountain gorillas (Gorilla beringei beringei) which spent their entire lives in their natural habitat also display an age-related increase in APP and/or A $\beta$-immunoreactive blood vessels and plaques, but very limited tau pathology, in the frontal cortex [46]. In contrast, old-age baboons (Papio hamadryas) show NFTs in the hippocampus and limbic system, and tau-positive inclusions in astrocytes located in subependymal, subpial and perivascular locations, as well as in oligodendrocytes [47]. The first description of AD-like neuropathology in an aged chimpanzee (Pan troglodytes) included tau deposits in neurons, neuropil threads and plaque-like clusters throughout the neocortex with moderate $A \beta$ deposition in blood vessels and rarely in plaques [48]. Subsequent studies in a larger series of chimpanzees revealed $A \beta$ plaques, A $\beta$-angiopathy, and neurons with pre-tangles, NFTs and neuritic clusters [49].

Cerebral $A \beta$ deposition is found in aged cotton-top tamarins (Saguinus oedipus), lemurs (Lemuroidae), marmosets, cynomologous monkeys, rhesus monkeys (Macaca mulatta), vervets (Chlorocebus pygerythrus), squirrel monkeys (Saimiri sp.), baboons, orangutans (Pongo sp.), gorillas and chimpanzees [50]. The amyloid precursor protein and its shorter fragment, $\mathrm{A} \beta$, are homologous in humans and non-human primates. However, MAPT sequence varies among primates, with differences being minimal between human and chimpanzees. This may account for differences between humans and non-human primates regarding tau pathology in old-age and related tauopathies [51]. Further studies are needed to elucidate possibly overlooked tau deposition in glial cells, and additional abnormal tau-containing deposits such as grains in aged non-human primates.

\section{Main Types of Tau-Containing Astrocytes}

Astrocytes containing hyper-phosphorylated tau have disease-specific traits in the majority of tauopathies: tufted astrocytes in PSP, astrocytic plaques in CBD, thorn-shaped astrocytes (TSAs) and granular/fuzzy astrocytes (GFAs) in ARTAG, ramified astrocytes in PiD and astrocytes with globular inclusions in GGT [4,17,18,20,24,25,52-66]. (Figures 1-3).
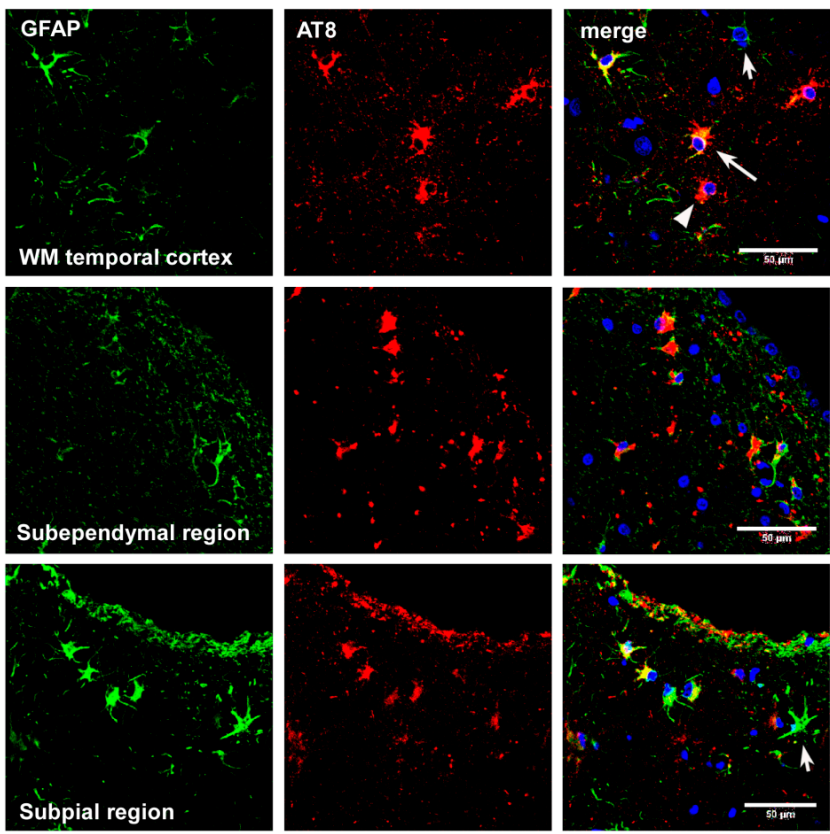

Figure 1. Double-labeling immunofluorescence to glial fibrillary acidic protein (GFAP) (green) and phospho-tau AT8 (red) showing the morphology of thorn-shaped astrocytes in the white matter of the temporal cortex, subependymal region and subpial region. Long arrow: cells with double staining; short arrow: cells only stained green; arrowhead: cells only stained red. Hyper-phosphorylated tau-containing astrocytes have reduced GFAP immunoreactivity. Paraffin sections; nuclei (blue) are stained with DRAQ5 (Biostatus, Leicestershire, UK); WM: withe matter; bar $=50 \mu \mathrm{m}$. 


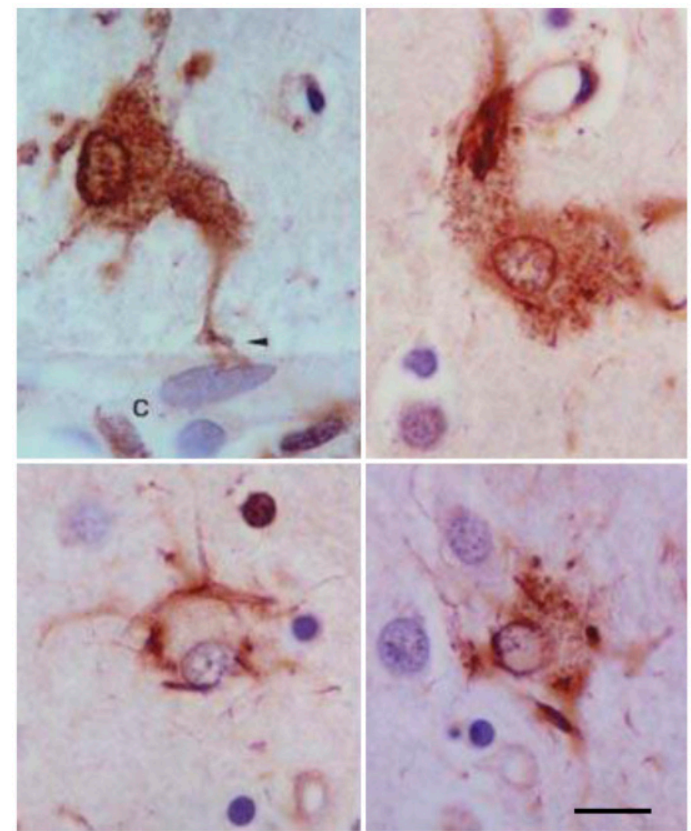

Figure 2. Tau-containing astrocytes in progressive supernuclear palsy (PSP). Typical tufted astrocytes are seen in the lower row. A perivascular astrocyte with a podocyte (arrowhead) in the vicinity of a capillary (C), and a reactive astrocyte also contain hyper-phosphorylated tau (upper row). Paraffin section, AT8 immunohistochemistry, slightly counterstained with hematoxylin, $b a r=10 \mu \mathrm{m}$.

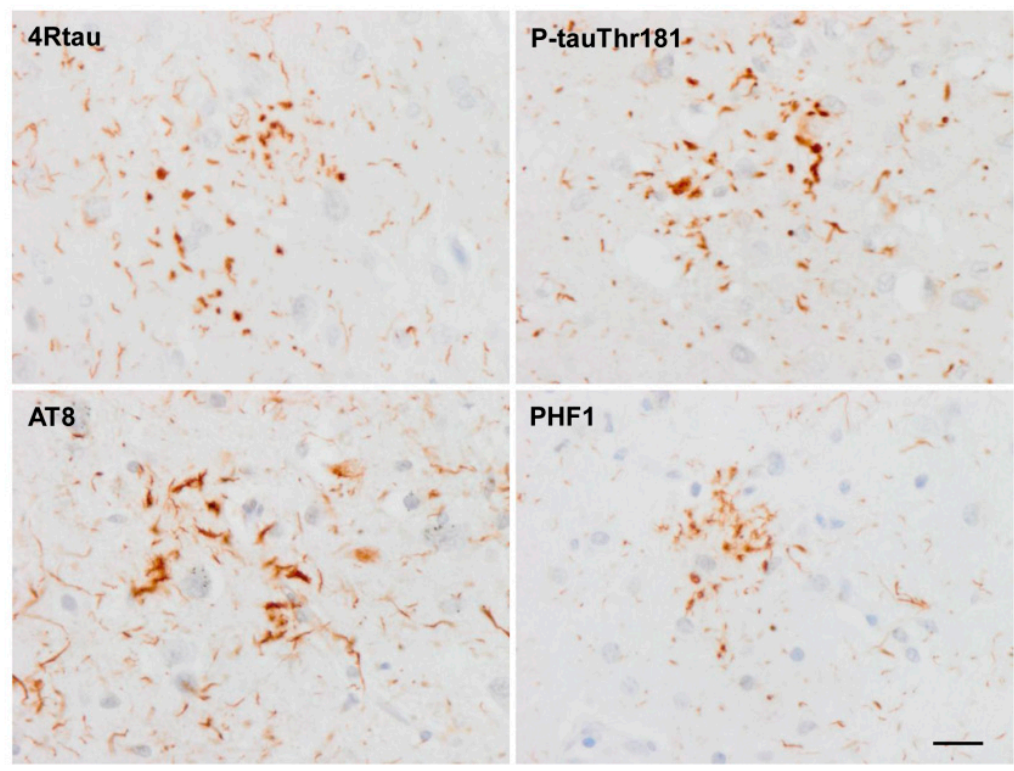

Figure 3. Astrocytic plaques in corticobasal degeneration (CBD), stained with 4Rtau, P-tauThr181, AT8 (P-tau Ser202-Thr205) and antibody PHF1 (P-tauSer396-Ser404). Paraffin sections slightly counterstained with hematoxilin, bar $=25 \mu \mathrm{m}$.

However, some tau-containing astrocytes are found in different tauopathies-for example, TSAs occur in aging, AGD, AD, PSP and CBD [14,19,67-72], and in traumatic chronic encephalopathy [73]. Granular/fuzzy astrocytes are seen in the elderly and ARTAG [26,70], but also in other tauopathies such as in PSP [37].

Interestingly, tau-containing astrocytes are early lesions in PSP, CBD and FTLD-tau [28,74-76]. 
Various types of astrocytic inclusions are generated in familial FTLD-tau linked to mutations in exons 1 and 10 and in introns following exons 9 and 10, the morphology of which largely depends on the MAPT mutation. Intracytoplasmic tau-immunoreactive inclusions in FTLD-tau are represented by tufted-like astrocytes, astrocytic plaques, ramified astrocytes, TSAs, astrocytes with globular inclusions and other types with no specific names $[17,33,34,36,37,66,77-86]$. Tufted astrocytes and astrocytic plaques practically do not co-exist in PSP and CBD [57], but these lesions appear in combination in FTLD-tau [29] (Figure 4).

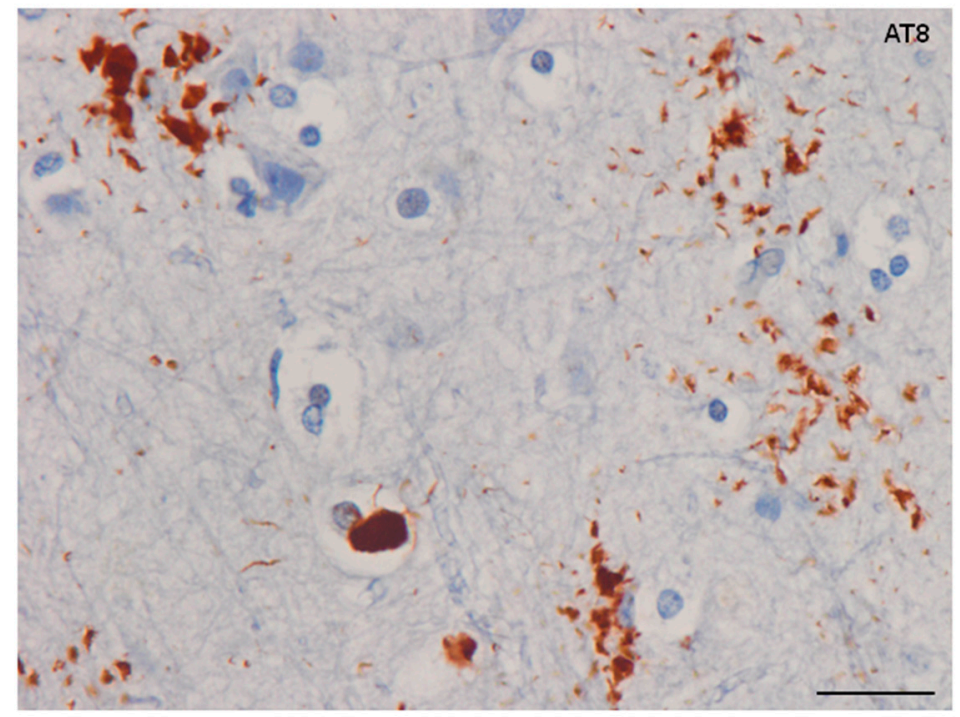

Figure 4. Frontotemporal lobar degeneration linked to MAPT mutations (FTLD-tau) K317M stained with antibody AT8 showing tufted-like astrocytes (reminiscent of tau-containing astrocytes in globular glial tauopathy (GGT)), astrocytic plaques and globular inclusion in an oligodendrocyte. Paraffin sections, slightly counterstained with hematoxylin, bar $=25 \mu \mathrm{m}$.

Extensive astrocyte-predominant tauopathy involving brain astrocytes and Bergmann glia has been reported in familial behavioral variant frontotemporal dementia associated with astrocyte-predominant tauopathy; the morphology of abnormal astrocytes, including deposits in Bergmann glia, differs from all other tauopathies [87].

The localization of tau-containing astrocytes does not always match that of tau-containing neurons in tauopathies [14,19,28,76,88-92]. Curiously, tufted astrocytes and astrocytic plaques are often located near the blood vessels [93], and perivascular distribution is overwhelming in a rare familial behavioral variant frontotemporal dementia associated with astrocyte-predominant tauopathy [87]. Regarding ARTAG, TSAs are found in regions proximal to the CSF and blood vessels [72].

Hyper-phosphorylated tau intracytoplasmic filamentous inclusions are common in transgenic mouse models of tauopathies both in animals over-expressing human tau and those bearing different tau mutations which are causative of human familial FTLD-tau. Tau pathology in glial cells has been generated in transgenic mice over-expressing human tau in neurons and glial cells. In these animals, a tau pathology resembling astrocytic plaques and coiled bodies in oligodendrocytes is found in old mice; these changes are associated with glial and axonal degeneration [94].

Transgenic mice bearing P301L tau develop cytoplasmic neuronal inclusions, and oligodendroglial and astrocytic filamentous inclusions composed of abnormal hyper-phosphorylated tau aggregates [95]. Similar neuronal and glial tau-immunoreactive inclusions occur in the P301S transgenic mouse (Figure 5). 

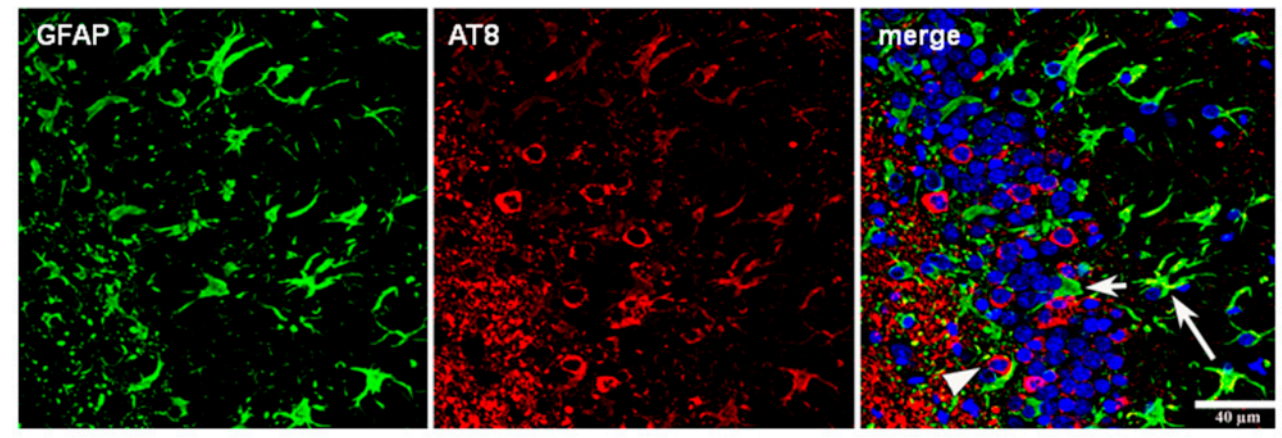

Figure 5. P301S transgenic mice aged 10 months. Double-labeling immunofluorescence to GFAP (green) and AT8 (red) showing cells with double staining (long arrow), cells only stained green (short arrow) and cells only stained red (arrowhead). Some astrocytes contain hyper-phosphorylated tau deposits. Paraffin sections; nuclei stained with DRAQ5 (Biostatus) (blue); bar $=40 \mu \mathrm{m}$.

\section{Post-Translational Tau Modifications and Tau Kinases in Tau-Containing Astrocytes in Tauopathies}

Tau in astrocytes is hyper-phosphorylated at different sites including Thr181, Ser199, Thr231, Ser262, Ser422, Ser202-Thr205 (antibody AT8), Ser396-Ser404 (antibody PHF1) and Thr212/Ser214 (tau-100), and it has an altered conformation as revealed with the antibodies Alz50 (amino acids 5-15) and MC-1 (amino acids 312-322) [37]. All these astrocytic inclusions in sporadic tauopathies are composed of 4 Rtau isoforms, but certain astrocytes in PiD and PSP contain 3Rtau [37]. Astrocytic inclusions in FTLD-tau depend on the mutation, but they are largely composed of 4Rtau $[33,37,66]$.

Astrocytes containing hyper-phosphorylated tau inclusions co-express phosphorylated tau kinases: mitogen-activated protein kinase/extracellular signal-regulated kinase (MAPK/ERK), p-38 kinase, stress-activated kinase/c-Jun N-terminal kinase (SAPK/JNK) and glycogen synthase kinase-3 [14,82,96-100]. Co-expression in astrocytes suggests active phosphorylation of tau by specific kinases; such co-localization also occurs in neurons with pre-tangles and tangles in the same tauopathies.

The presence of truncated forms of tau in tau-containing astrocytes is not documented in detail. Most tau-containing astrocytes in tauopathies are not stained with the antibody tau-C 3 which recognizes tau truncated at aspartic acid 421 [37]. Only small tau-C3 immunoreactive dots are occasionally seen in TSAs [71]. Exceptions are astrocytes with globular inclusions in GGT, astrocytes in certain FTLD-tau (as in the familial tauopathy linked to MAPT K317M), and astrocytes in familial behavioral variant frontotemporal dementia associated with astrocyte-predominant tauopathy $[37,87]$. In such cases, tau-containing astrocytes are always ubiquitinated [37]. In contrast, tufted astrocytes, astrocytic plaques, TSAs and ramified astrocytes only very rarely contain ubiquitin-immunoreactive deposits [37] (Figure 6). 


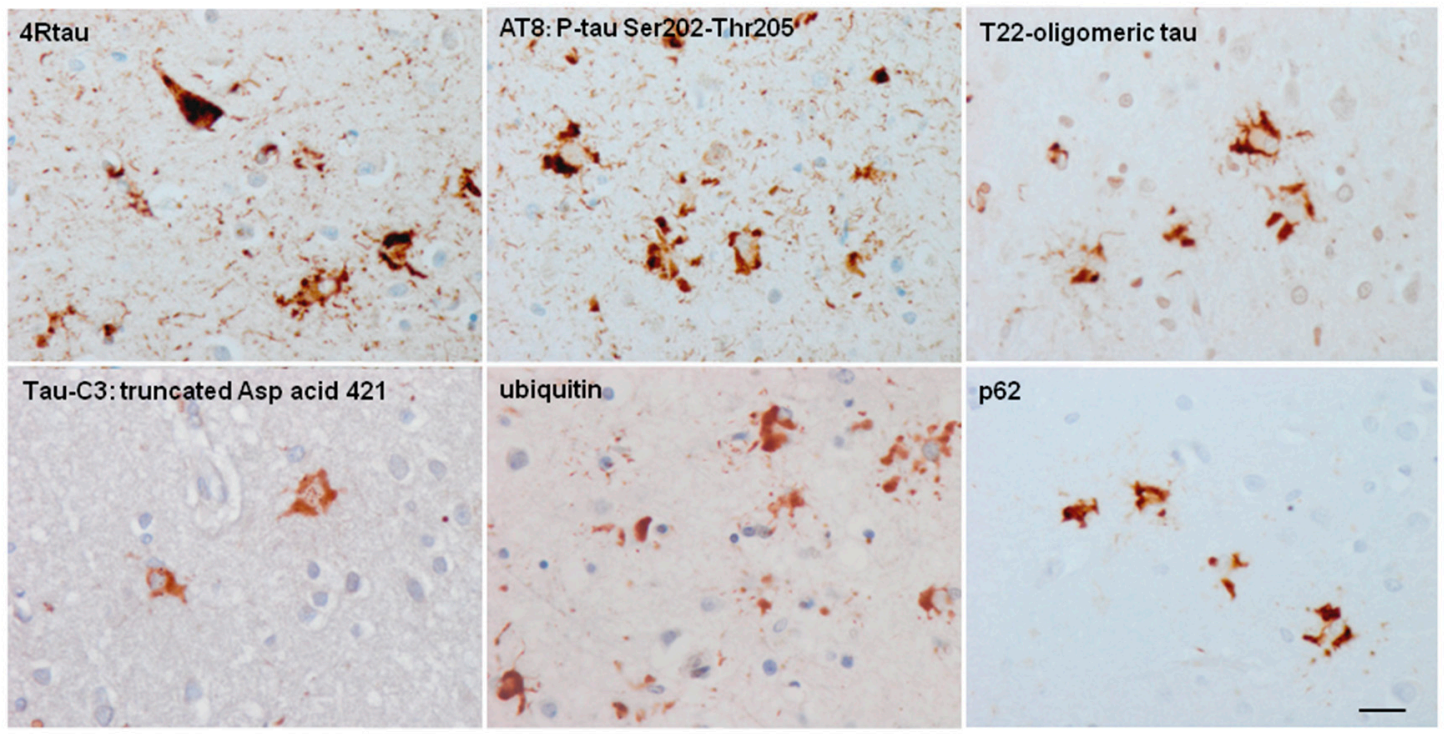

Figure 6. Globular glial tauopathy (GGT) showing abnormal tau-containing astrocytes with distinctive features stained with antibodies against 4Rtau, clone AT8 (directed against P-tau Ser202-Thr205), tau22 (anti-oligomeric tau), tau-C3 (against tau truncation at aspartic acid 421), ubiquitin and p62. One neuron is also observed in the section stained with anti-4Rtau. Paraffin sections slightly counterstained with hematoxylin, bar $=25 \mu \mathrm{m}$.

Tau phosphorylation, conformation and truncation in astrocytes have characteristics similar to their neuronal counterparts in tauopathies with equivalents to pre-tangles and tangle stages [37]. However, this must be interpreted with caution as knowledge is still limited. For example, a lack of epitopes derived from alternatively spliced exon 2 and 3 has been reported in glial tau when compared with neuronal tau in certain tauopathies $[56,101]$. Tau acetylation is rarer in astrocytes when compared to neurons in tauopathies [102]. Tau is acetylated in glial inclusions in FTLD-tau [102] but apparently not in AGD [103]. This is an important point, as tau acetylation inhibits tau function and promotes tau aggregation [104,105].

Finally, tau truncation may occur at different sites of tau; western blots of total brain homogenates show bands of low molecular weight in most tauopathies, but the method does not discriminate between neurons and glial cells. Immunohistochemistry utilizing tau antibodies directed against specific amino acids of tau (amino-terminal, carboxyl-terminal, middle segments) can be useful to uncover possible sites of tau truncation in astrocytes in tauopathies in addition to the characteristic truncation at aspartic acid 421 in astrocytes in minority tauopathies. Thorn-shaped astrocytes (TSAs) are stained with antibody 394 (amino acids 394-398, corresponding to the carboxyl-terminal); antibody 229 (against amino acids 229-233, middle region) and antibody 499 (directed against amino acids 14-26, amino-terminal) [106]. Tau-containing astrocytes in FTLD-tau 301T are stained with antibodies tau 7 (directed against amino acids 426-441), 394, 229 and 499 (Figure 7A). However, tufted astrocytes in PSP and astrocytic plaques in CBD are decorated with antibodies tau 7, 229 and 394 but barely or not at all with antibody 499 , thus suggesting the reduction or absence of tau species containing the amino terminal of tau protein in tufted astrocytes and astrocytic plaques (Figure 7B,C). 


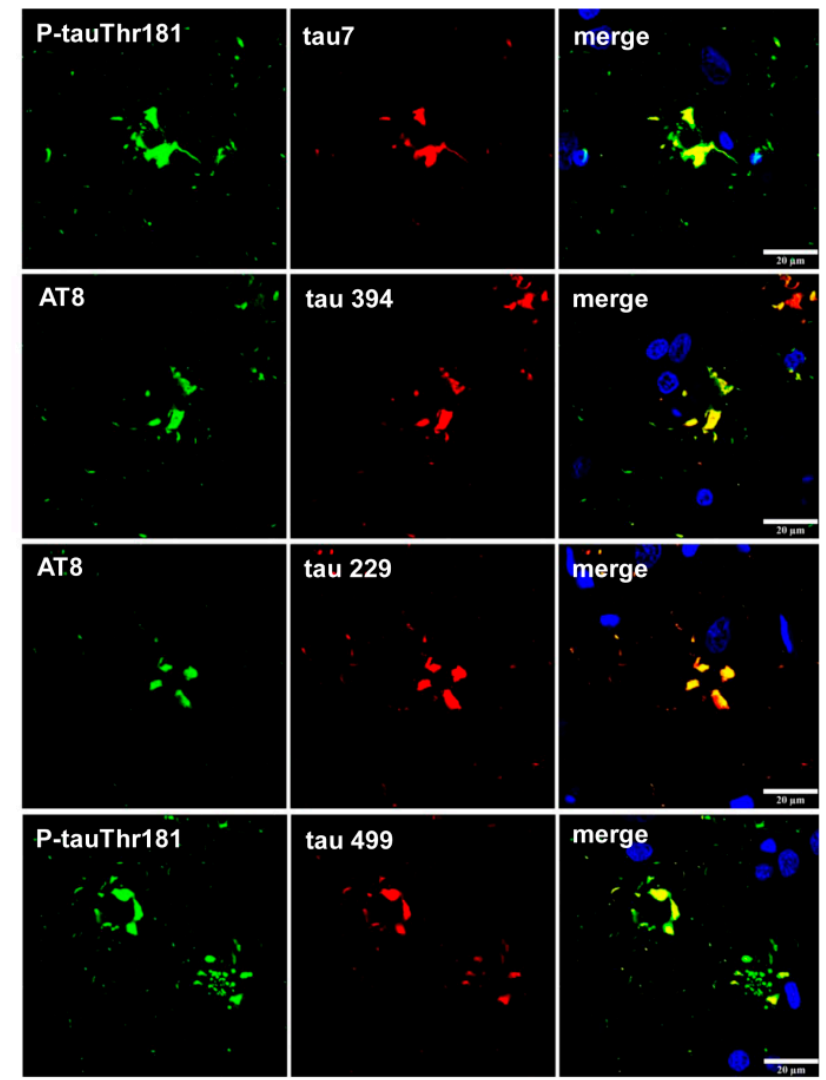

(A)

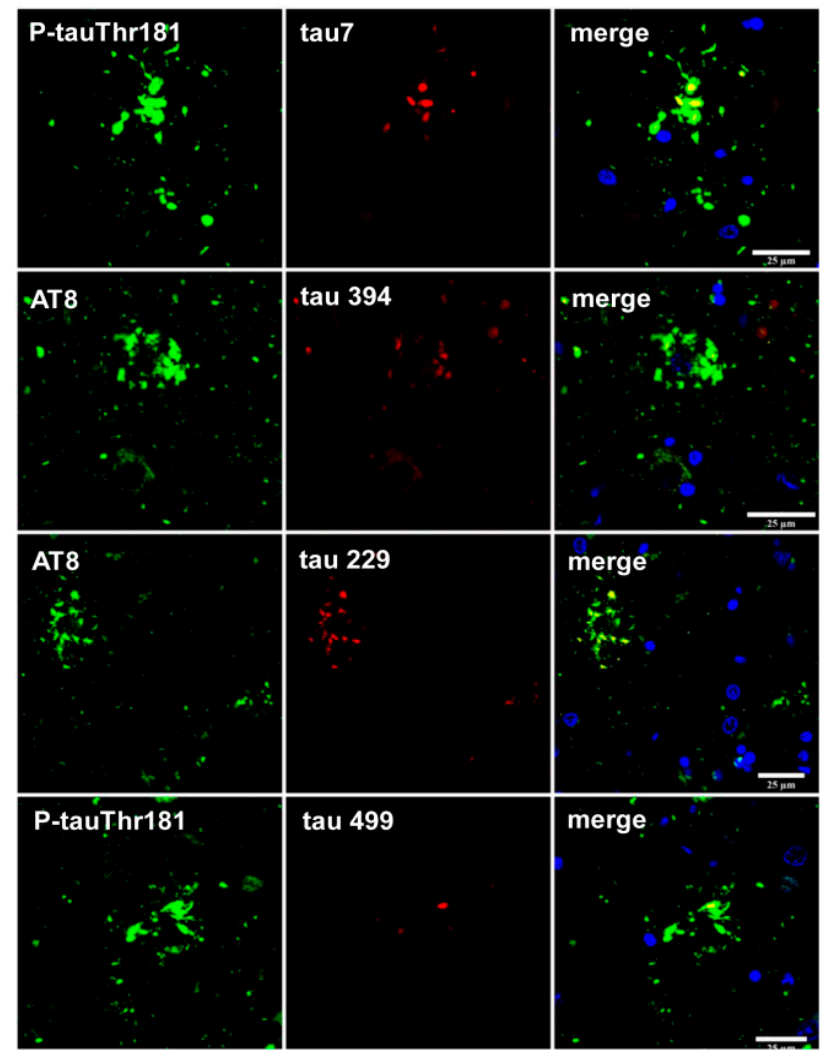

(B)

Figure 7. Cont. 


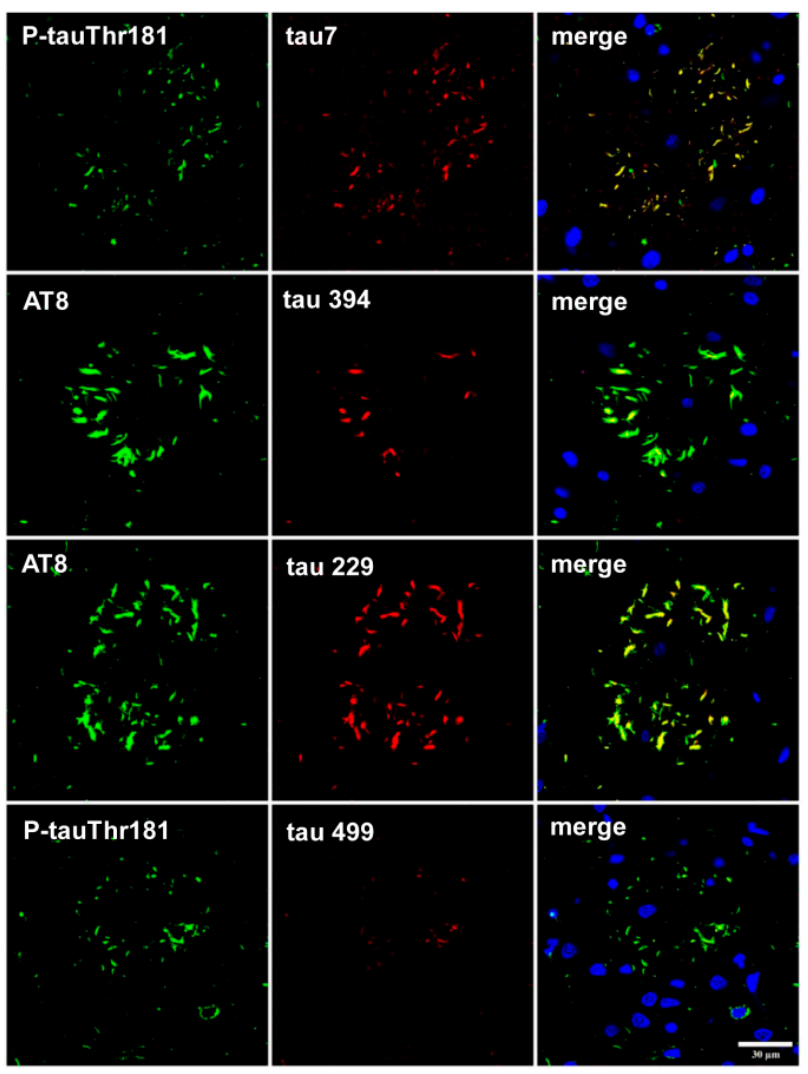

(C)

Figure 7. Double-labeling immunofluorescence and confocal microscopy using antibodies tau 7 (directed against amino acids 426-441), 394 (amino acids 394-398, corresponding to the carboxyl terminal), 229 (against amino acids 229-233, middle region), and 499 (directed against amino acids 14-26, amino terminal) (green); and P-tauThr181 or AT8 (depending on the mouse or rabbit origin of the first anti-tau antibodies) (red) in FTLD-tau linked to 301T mutation (A); PSP (B) and CBD (C). Tau 7, 229 and 394 co-localize with phospho-tau deposits in astrocytes in FTLD-tau 301T, tufted astrocytes and astrocytic plaques; antibody 499 also co-localizes with phospho-tau in FTLD-tau 301T, but tufted astrocytes and astrocytic plaques almost lack 499 tau immunostaining, thus suggesting tau amino terminal truncation. Paraffin sections; nuclei (blue) are stained with DRAQ5 (Biostatus); A, bar= $20 \mu \mathrm{m}$; $\mathrm{B}, \mathrm{bar}=25 \mu \mathrm{m} \mathrm{C}$; bar $=30 \mu \mathrm{m}$.

\section{Cytoarchitectonic Changes Linked to Tau Deposits in Astrocytes}

Not all astrocytes are immunoreactive to glial fibrillary acidic protein (GFAP) [107-110]. However, GFAP is currently used as a marker of astrocytes, mainly for reactive astrocytes.

Even considering these limitations, double-labeling immunofluorescence and confocal microscopy have been used to learn about cytoskeletal anomalies in astrocytes containing hyper-phosphorylated tau. Glial fibrillary acidic protein has been reported to be absent in tufted astrocytes in PSP $[58,111]$. However, small amounts of GFAP are commonly redistributed around the nucleus in tufted astrocytes in PSP and FTLD-tau. GFAP is disrupted by short segments or dots of hyper-phosphorylated tau throughout the astrocytic processes in astrocytic plaques in CBD, and in astrocytes with proximal granular inclusions in FTLD-tau/P301L. Glial fibrillary acidic protein immunoreactivity is also displaced by hyper-phosphorylated tau deposits in ramified astrocytes in PiD, TSAs in ARTAG, tau-containing astrocytes in GGT, and astrocytes in familial behavioral variant frontotemporal dementia associated with astrocyte-predominant tauopathy $[37,87,92]$ (Figure 8). 

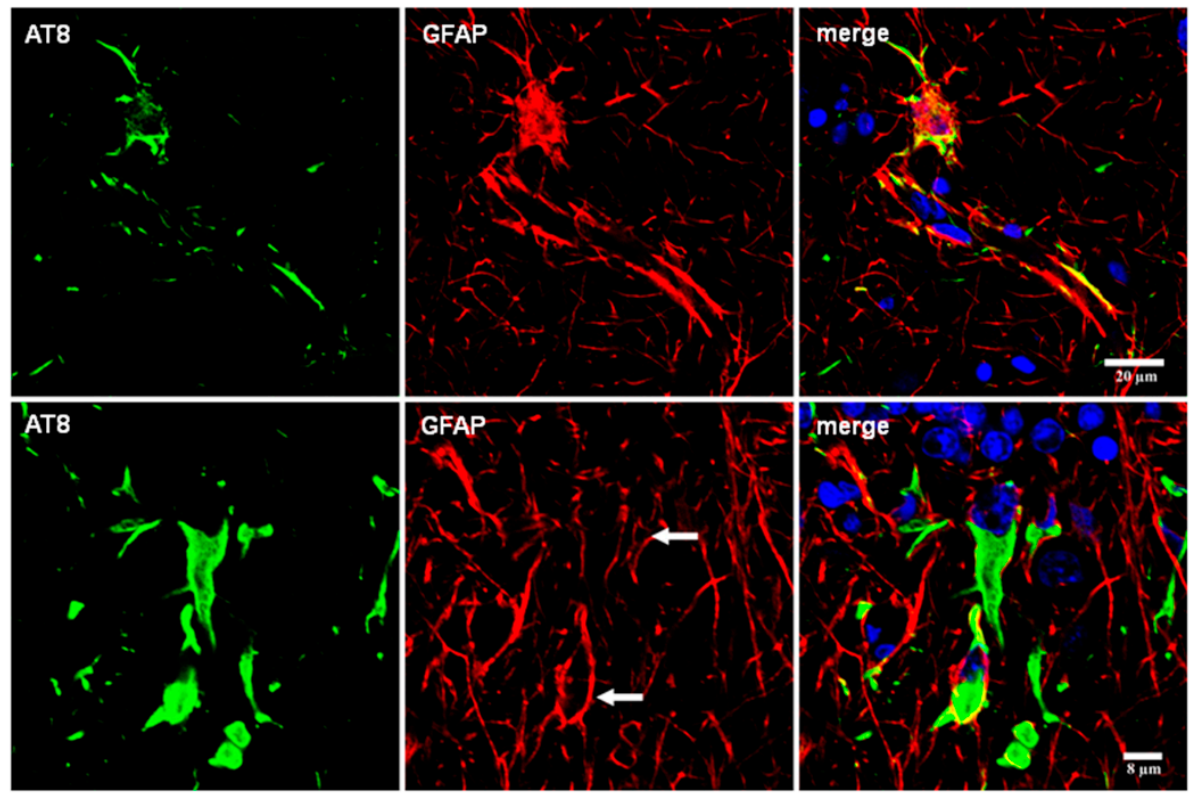

Figure 8. Double-labeling immunofluorescence and confocal microscopy to phospho-tau clone AT8 (green) and glial fibrillary acidic protein (red) in the cerebral cortex (upper row) and cerebellum (lower row) in familial behavioral variant frontotemporal dementia associated with astrocyte-predominant tauopathy. Variable distortion of the glial cytoskeleton is found mainly in Bergmann glia. Nuclei are stained with DRAQ5 (Biostatus) (blue). Upper row, bar $=20 \mu \mathrm{m}$; lower row, bar $=8 \mu \mathrm{m}$.

\section{Astrogliopathy}

This term refers to alterations of astrocytes occurring in diseases of the nervous system, implying the involvement of astrocytes as key elements in the pathogenesis and pathology of diseases and in injuries of the central nervous system [112-122].

Reactive astrogliosis is a reaction secondary to neuronal damage in various injuries such as trauma and ischemia, external toxins, metabolic disorders and neurodegenerative diseases. The term astrocytopathy is used for non-reactive astrogliosis including hypertrophy, atrophy and astroglial degeneration with loss of function manifested by variable and distinct molecular changes in astrocytes, and pathological remodeling $[112,117]$. Senescent astrocytes are a particular form of astrocytophathy linked to old age which is manifested by modifications in the morphology of the nucleus and cytoplasm, cytoskeletal changes, oxidative damage, reduced energy production and secretory phenotype including production of inflammatory cytokines [92].

\section{Reactive Astrogliosis}

Reactive astrogliosis is common to all tauopathies and its distribution correlates with the degree of regional vulnerability to neuronal degeneration and neuronal loss $[17,123,124]$. However, tau-containing astrocytes do not match reactive astrocytes and they represent different although occasionally co-existent lesions $[17,18,92,124]$.

Reactive astrogliosis also occurs in transgenic mouse models; the hippocampus is mainly affected in mice bearing the P301S mutation [125].

The expression of small heat shock proteins (HSP25/27 and $\alpha \mathrm{B}$-crystallin) is a characteristic response of reactive astrocytes in most tauopathies. However, HSPs are rarely co-expressed in astrocytes containing hyper-phosphorylated tau [126-129] (Figure 9). This suggests that generalized stress, rather than the restricted response in glial cells with abnormal protein aggregates, induces HSP expression [129]. Alternatively, it may be postulated that stress responses are directed to correcting 
protein misfolding, and that they succeed to a certain extent, in that aggregates are not formed in many glial cells [92].
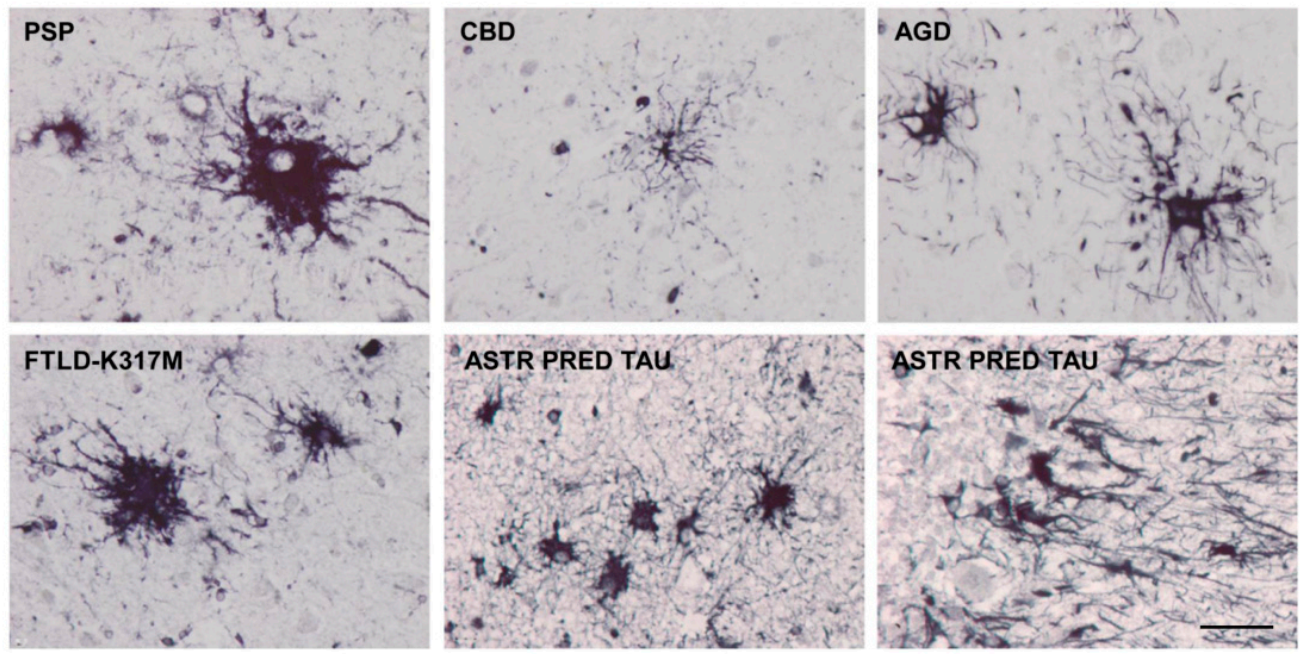

Figure 9. $\alpha B$-crystallin-immunoreactive astrocytes in PSP, CBD, argyrophilic gain disease (AGD), FTLD-tau K317M and familial behavioral variant frontotemporal dementia associated with astrocyte-predominant tauopathy. Paraffin sections visualized with diaminobenzidine, $\mathrm{NH}_{4} \mathrm{NiSO}_{4}$ and $\mathrm{H}_{2} \mathrm{O}_{2}$ without hematoxylin counterstaining; bar $=50 \mu \mathrm{m}$.

Additionally, it has been reported that intraneuronal accumulation of misfolded tau protein induces over-expression of Hsp27 in activated astrocytes [130].

\section{Astrocytopathy}

In spite of the evident astrocytopathy characterized by disease-dependent stereotyped tau deposits, little is known about the functional effects of hyper-phosphorylated tau in tau-containing astrocytes in tauopathies [131]. This is due to several factors: the diversity of astrocytes, diversity of functions and gene expression profiles under various conditions and regions, as well as the lack of studies considering these variables in tauopathies.

Astrocytes are not homogeneous cells. They can be classified into protoplasmic astrocytes of the grey matter, interlaminar astrocytes of the cerebral cortex, subpial astrocytes of the cerebral cortex, fibrous astrocytes of the white matter, perivascular astrocytes, Bergmann glia, stem astrocytes of subventricular zones, radial glia of the developing brain, tanycytes of the hypothalamus, pituicytes and Müller glia of the retina [116]. Moreover, they are heterogeneous with respect to their coverage domains, ion channels, calcium responses, glutamate transporters and expression of neurotransmitter receptors [92,132].

Gene expression studies of neurons and glial cells have contributed to our understanding of the variety of gene expression profiles that advance distinct functions in different cell types [133-140]. Microarray analyses of isolated astrocytes have identified particular transcription profiles in AD and related animal models [141,142].

Unfortunately, this approach has not been utilized in human tauopathies, and we are still in the dark concerning gene expression differences among TSAs, tufted astrocytes, astrocytic plaques and astrocytes with globular inclusions, to name just some examples.

Moreover, we do not know about similarities and differences among tau-containing astrocytes in the same disease but located in different regions; for example, subependymal, subpial, clusters in the frontal and temporal white matter, basal forebrain and perivascular TSAs in ARTAG. 
These aspects are important in the present context as we do not know whether different tau inclusions affect different astrocyte types with particular vulnerability to tau species, or even if different tau species modify the morphology and function of the same type of astrocyte.

The over-expression of tau in cultured astrocytes produces degeneration of the cytoskeleton and Golgi complex, eventually leading to cell death [143]. Altered nuclear function and DNA transcription has also been posited for tau-containing neurons in tauopathies and fly models [144-147].

The expression of solute carrier family 1 member 2 (SLC1A2 or GLT-1) is markedly reduced in most astrocytes bearing hyper-phosphorylated tau in familial behavioral variant frontotemporal dementia associated with astrocyte-predominant tauopathy [87]. Decreased expression of GLT-1 and solute carrier family 1 member 3 (SLC1A3 or GLAST) also occurs in transgenic mice selectively expressing hyper-phosphorylated tau in astrocytes [148,149].

Whether tau-containing astrocytes have deleterious effects on neurons is an important question, as decreased GLT-1 expression alters glutamate metabolism and enhances excitoxicity. Hyper-phosphorylated tau deposits also have effects on the redistribution of organelles and reactive responses, but their functional effects are not known (Figure 10).
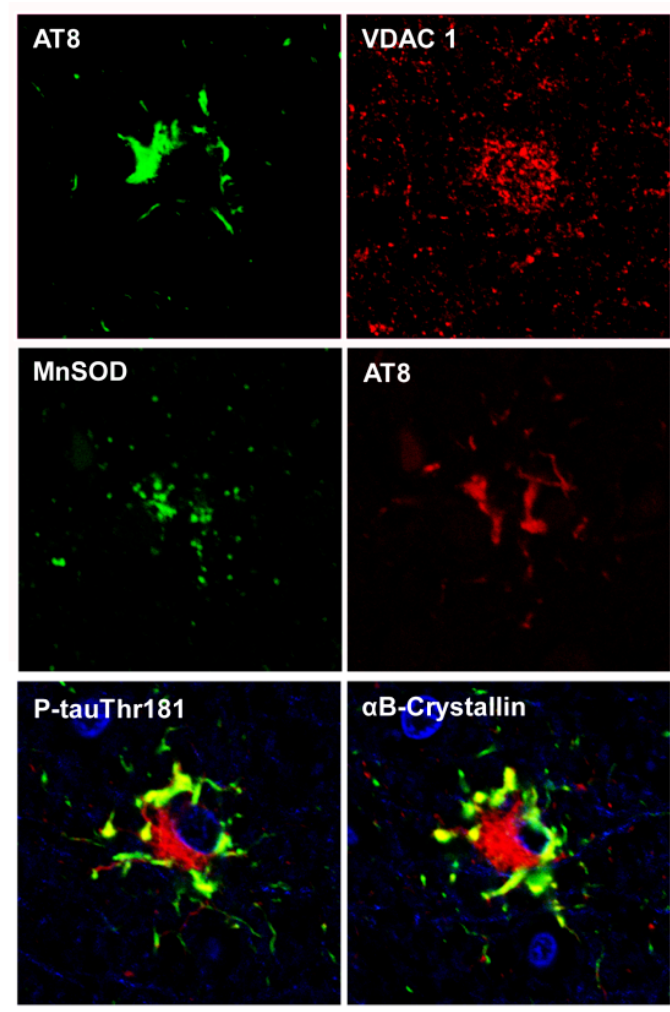
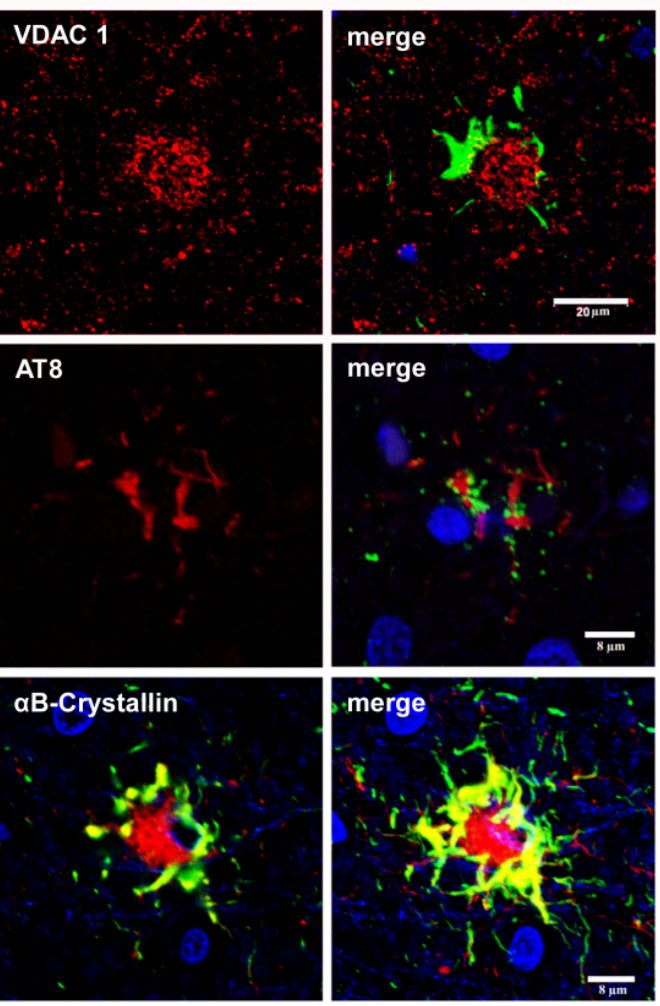

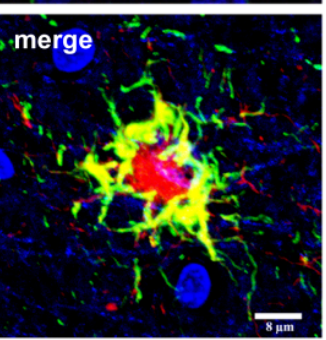

Figure 10. Double-labeling immunofluorescence and confocal microscopy of tufted astrocytes in PSP to AT8 and voltage-dependent anion-selective channel 1: VDAC1 (upper row), AT8 and superoxide dismutase 2: MnSOD, SOD2 (middle row), and serial sections of P-tauThr181 and $\alpha \mathrm{B}$-crystallin (lower row). VDAC1 is concentrated at the center of the cell due to the displacement of peripheral tau whereas SOD2 immunoreactivity is intermingled with phospho-tau deposits. $\alpha$ B-crystallin is found around the nucleus and surrounded by hyper-phosphorylated tufts. Paraffin sections; nuclei (blue) are stained with DRAQ5 (Biostatus); upper row, bar $=20 \mu \mathrm{m}$; middle and lower row, bar $=8 \mu \mathrm{m}$.

Moreover, extracellular tau oligomers rapidly accumulate in astrocytes and reduce the release of gliotransmitters, thus impairing neuronal function [150].

Furthermore, FTLD-N279K MAPT astrocytes derived from neural stem cells increase oxidative stress and produce marked modifications in the genomic expression of co-cultured healthy 
neurons [151]. Finally, P301S-derived astrocytes significantly decrease pre-synaptic and post-synaptic protein expression in cortical neuron cultures, whereas normal astrocytes enhance these markers, thereby suggesting that mutant astrocytes have reduced neuroprotective capacities [152].

\section{Disease Progression: Seeding and Spreading; Role of Astrocytes}

Tauopathies are progressive biological processes with a preclinical phase, prodromal phases and phases with clinical manifestations. The stages of NFT progression (stages I-VI of Braak) in AD are well known $[153,154]$. The stages of NFT pathology in PART are the same as those proposed for AD; whether PART is part of AD is a matter of discussion $[155,156]$. The majority of cases formerly classified as early stages of sporadic AD lack A $\beta$ plaques $[157,158]$ and are now considered PART, whereas the majority of cases with advanced Braak NFT stages are considered AD because of the presence of abundant $A \beta$ deposits. Whatever the name, early stages of NFT are very common in old people as they occur in about $85 \%$ of individuals aged 65 years $[157,159]$.

Different stages have also been proposed to categorize disease progression in AGD [14,160]. In contrast, only short series of incidental and early stages of PSP and CBD are available [74-76,161,162] to permit a validation of the several proposed sequences of events in disease progression.

The progression of $\mathrm{AD}$ and tauopathies is thought to occur by trans-cellular and trans-regional propagation of the abnormal protein in a similar way to what happens in prion diseases [163]. The exact mechanism of transmission is not known. Release and trans-synaptic transmission of tau [164,165], tau uptake via exosomes [166-168] or nanotubules [169] and free uptake of fibrillar proteins $[170,171]$ have all been suggested as putative mechanisms using cultured neurons. Although astrocyte-to-neuron intercellular transfer mediated by cell-to-cell contact has been postulated for prions [172], no information is available concerning astrocyte-to-neuron transfer in tauopathies.

Transgenic mice with human tau over-expression or with tau mutations have been used to facilitate the mechanism of seeding and progression. Seeding and spreading of abnormal tau occurs after inoculation of brain homogenates from $\mathrm{AD}$ and other tauopathies into the brain of transgenic mice over-expressing human tau or mutated tau [163,173-175]. The type of deposits in the inoculated animals seems to be disease-dependent in the few tauopathies so far studied, which suggests the occurrence of different species or strains of tau depending on the disease [176-178]. However, these models have a natural substrate of abnormal tau production that makes it difficult to separate the propagation itself from what is induced.

Seeding of human tau from homogenates of AD and tauopathies with neuronal and glial components is also observed after inoculation into the brain of wild-type mice [178,179].

Additionally, the inoculation effect of recombinant tau is different from the effects using human brain homogenates enriched with tau fibrils from brains with tauopathy [178]. This suggests that different species ('strains') of tau have different properties and produce different effects. Another difference between the inoculation of recombinant tau fibrils and inoculation of tau from human brain homogenates is the accompanying inoculation, in the latter, of a number of associated proteins and enzymes which represents a probably disease-specific environment with unexplored properties.

All these experiments have been performed using brain samples of tauopathies with tau pathology only in neurons or with tau pathology in neurons and in glial cells. Abnormal tau in these paradigms can spread to resident neurons, astrocytes and oligodendroglia [176-178]. In other words, certain tau prion strains have the capacity to induce tauopathy not only in neurons but also in glial cells [180] (Figure 11). 


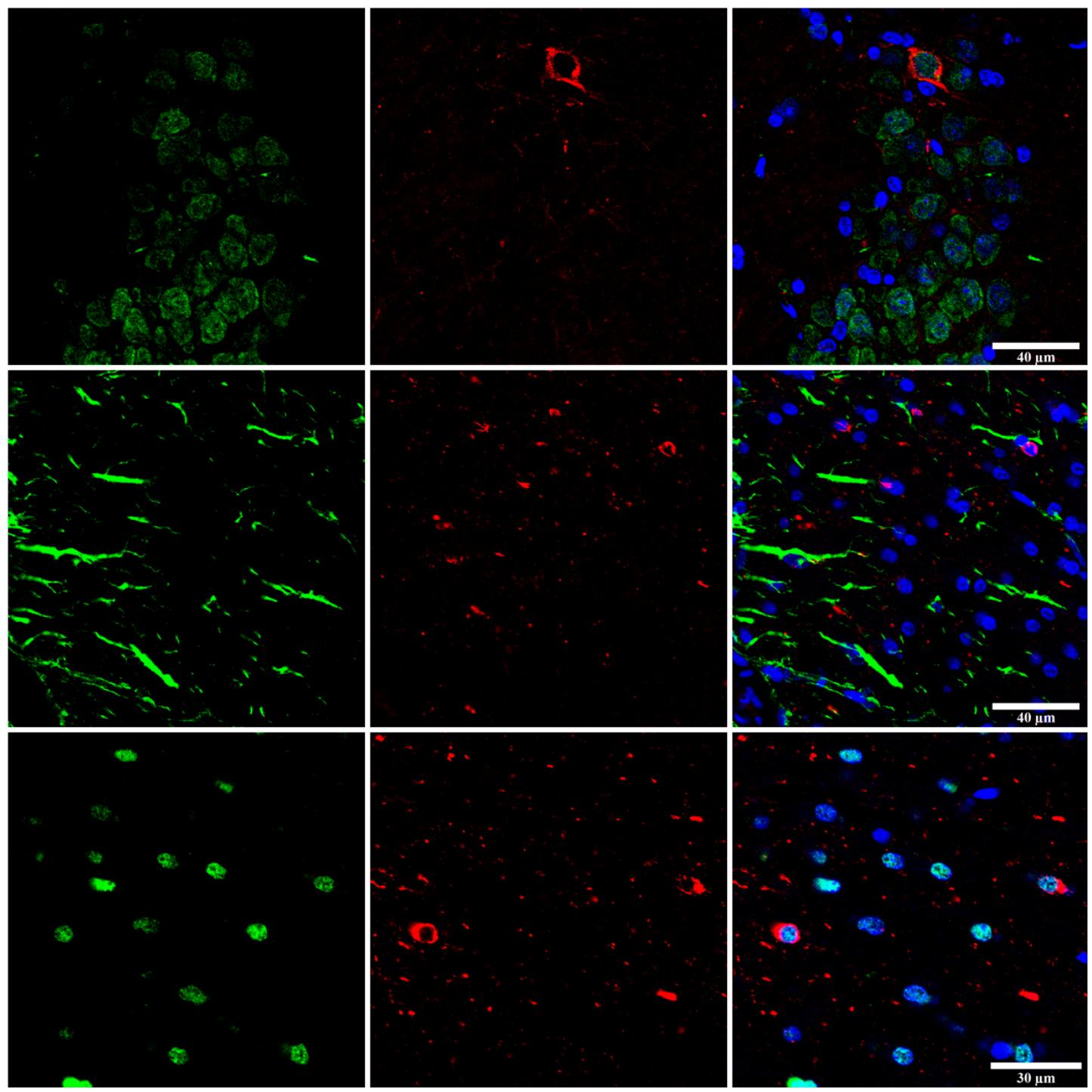

Figure 11. Wild-type (WT) mice inoculated with primary age-related tauopathy (PART) in the hippocampus at the age of 7 months and killed at the age of 10 months. Double-labeling immunofluorescence to neuronal nuclear protein (NeuN), GFAP and Olig-2 (green) and P-tauThr181 or clone AT8 (red). Subpopulations of neurons, astrocytes and oligodendrocytes contain hyper-phosphorylated tau (arrows). Paraffin sections, nuclei stained with DRAQ5 (Biostatus) (blue), bar, upper and middle row, bar $=30 \mu \mathrm{m}$; lower row, bar $=40 \mu \mathrm{m}$.

Whether astrocytic tau alone is able to induce tauopathy has recently been assessed. Tau-enriched fractions of brain homogenates from pure ARTAG (with no associated tauopathy) inoculated into the hippocampus (dentate gyrus and cornu ammonis (CA1) of wild-type mice generate intracytoplasmic hyper-phosphorylated tau inclusions in astrocytes, oligodendrocytes and neurons near the site of injection, and in nerve fiber tracts in the fimbria and corpus callosum [106] (Figure 12). These observations indicate that astrocytes containing hyper-phosphorylated tau have the capability of seeding tau to neurons and glial cells, thus highlighting the putatively cardinal role of astrocytopathy in the pathogenesis of tauopathies [106]. Moreover, inoculation of ARTAG, containing 4Rtau astrocytes, produces 3Rtau seeding in neurons and glial cells in addition to 4Rtau deposition [106]. This also points to the likely involvement of astrocytes in the development of tau-containing neuronal processes in the aged brain [181]. 


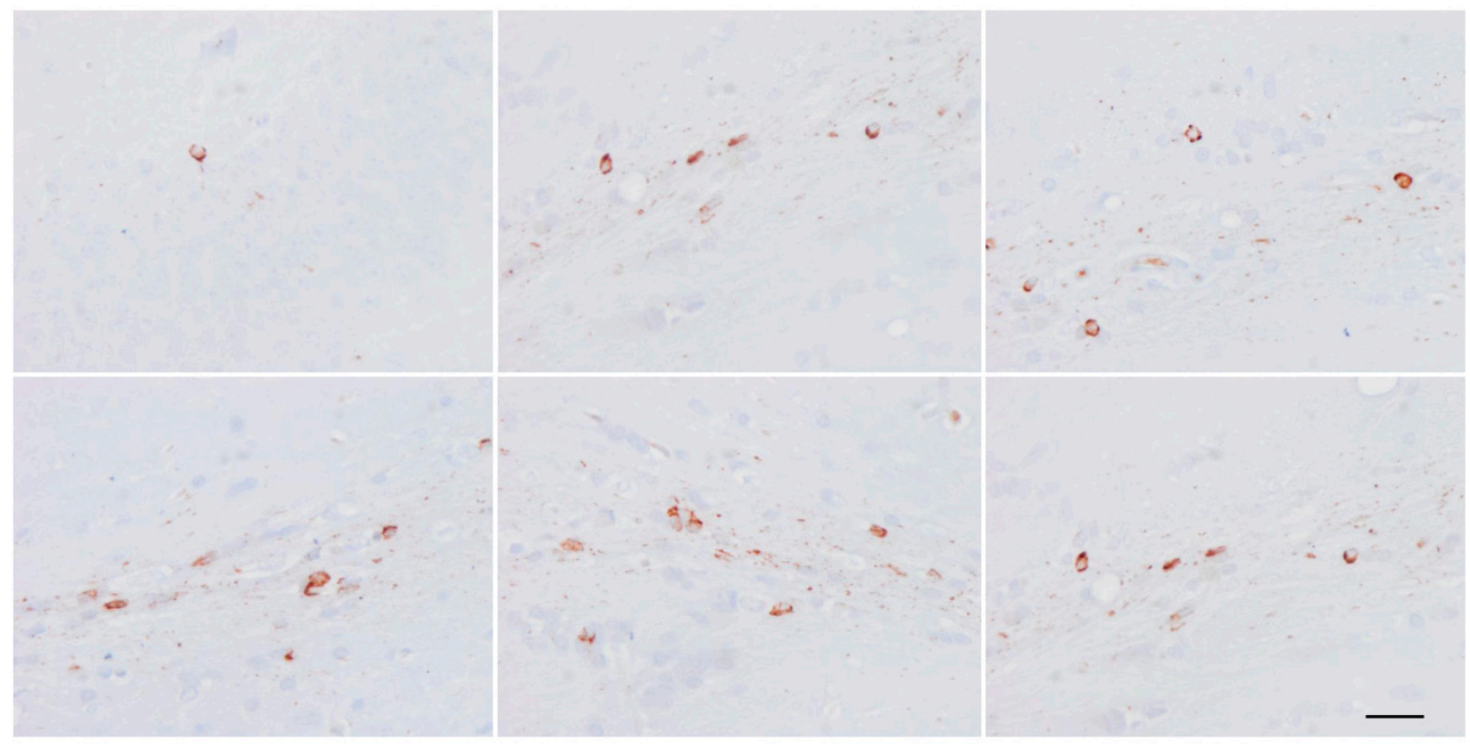

Figure 12. Wild-type mice inoculated with aging-related tau astrogliopathy (ARTAG) in the hippocampus at the age of 12 months and killed at the age of 19 months. The upper row corresponds to one mouse in which a hyper-phosphorylated tau-containing neuron is seen in CA1 region of the hippocampus (left) and several glial cells and fibers in the corpus callosum radiation of the ipsilateral side (middle) and contralateral side of injection (right). The lower row corresponds to another mouse showing hyper-phosphorylated tau fibers and glial cells in the corpus callosum radiation of the ipsilateral side (left), middle region of the corpus callosum (middle) and contralateral radiation of the corpus callosum (right). Paraffin sections immunostained with the AT8 antibody and slightly counterstained with hematoxylin, bar $=25 \mu \mathrm{m}$.

The fact that a neuronal tauopathy such as PART (only containing NFTs and threads) or pure forms of ARTAG (only containing TSAs) can produce seeding in neurons, astrocytes and oligodendrocytes in WT mice is an unexpected observation. This may be in part because different murine tau isoforms can be distinguished by the carboxyl terminal domains, and murine tau differs from human tau in a number of ways, including the absence of residues which are involved in tubulin binding [182].

Finally, environmental factors may influence tau pathology and seeding in astrocytes (and other cell types). Phosphoproteomics using bi-dimensional gel electrophoresis and mass spectrometry have shown a large number of phosphorylated proteins in addition to tau and related molecules in AD [183-185]. Other studies have identified GFAP phosphorylation in AD and in many other tauopathies [186,187]. More precise methods in several regions and different stages of disease have demonstrated the occurrence of very large numbers of phosphorylated proteins including kinases and synaptic proteins in areas with no relationship to $\beta$-amyloid deposits and NFTs [188]. Similar studies have recognized a number of phosphorylated proteins including phospho-kinases, neurofilaments, and synaptic and other neuronal proteins, in addition to phospho-GFAP and phosphorylated aquaporine-4 in the white matter in pure cases of ARTAG [106]. Although similar studies are not available in other tauopathies, these observations suggest that tau pathology in astrocytes should be interpreted not as an isolated process but in the context of a very particular environment which is hospitable to tau phosphorylation.

Funding: This study was funded by Ministry of Economy, Industry and Competitiveness, Institute of Health Carlos III (ISCIII-ERDF, a way to build Europe) PI17/00809, and co-financed by ERDF under the program Interreg Poctefa: RedPrion 148/16.

Acknowledgments: I wish to thank M. Carmona and B. Torrejón-Escribano for the preparation of figures and T. Yohannan for editorial help.

Conflicts of Interest: The author declares no conflict of interest. 


\section{References}

1. Tolnay, M.; Spillantini, M.G.; Goedert, M.; Ulrich, J.; Langui, D.; Probst, A. Argyrophilic grain disease: Widespread hyperphosphorylation of tau protein in limbic neurons. Acta Neuropathol. 1997, 93, 477-484. [CrossRef] [PubMed]

2. Molina, J.A.; Probst, A.; Villanueva, C.; Jimenez-Jimenez, F.J.; Madero, S.; Torres, N.; Bermejo, F. Primary progressive aphasia with glial cytoplasmic inclusions. Eur. Neurol. 1998, 40, 71-77. [CrossRef] [PubMed]

3. Jellinger, K.A. Dementia with grains (argyrophilic grain disease). Brain Pathol. 1998, 8, 377-386. [CrossRef] [PubMed]

4. Bigio, E.H.; Lipton, A.M.; Yen, S.H.; Hutton, M.L.; Baker, M.; Nacharaju, P.; White, C.L., 3rd; Davies, P.; Lin, W.; Dickson, D.W. Frontal lobe dementia with novel tauopathy: Sporadic multiple system tauopathy with dementia. J. Neuropathol. Exp. Neurol. 2001, 60, 328-341. [CrossRef] [PubMed]

5. Berry, R.W.; Quinn, B.; Johnson, N.; Cochran, E.J.; Ghoshal, N.; Binder, L.I. Pathological glial tau accumulations in neurodegenerative disease: Review and case report. Neurochem. Int. 2001, 39, 469-479. [CrossRef]

6. Ferrer, I.; Hernandez, I.; Boada, M.; Llorente, A.; Rey, M.J.; Cardozo, A.; Ezquerra, M.; Puig, B. Primary progressive aphasia as the initial manifestation of corticobasal degeneration and unusual tauopathies. Acta Neuropathol. 2003, 106, 419-435. [CrossRef] [PubMed]

7. Powers, J.M.; Byrne, N.P.; Ito, M.; Takao, M.; Yankopoulou, D.; Spillantini, M.G.; Ghetti, B. A novel leukoencephalopathy associated with tau deposits primarily in white matter glia. Acta Neuropathol. 2003, 106, 181-187. [CrossRef] [PubMed]

8. Clark, C.N.; Lashley, T.; Mahoney, C.J.; Warren, J.D.; Revesz, T.; Rohrer, J.D. Temporal Variant Frontotemporal dementia is associated with globular glial tauopathy. Cogn. Behav. Neurol. 2015, 28, 92-97. [CrossRef] [PubMed]

9. Piao, Y.S.; Tan, C.F.; Iwanaga, K.; Kakita, A.; Takano, H.; Nishizawa, M.; Lashley, T.; Revesz, T.; Lees, A.; de Silva, R.; et al. Sporadic four-repeat tauopathy with frontotemporal degeneration, parkinsonism and motor neuron disease. Acta Neuropathol. 2005, 110, 600-609. [CrossRef] [PubMed]

10. Josephs, K.A.; Katsuse, O.; Beccano-Kelly, D.A.; Lin, W.L.; Uitti, R.J.; Fujino, Y.; Boeve, B.F.; Hutton, M.L.; Baker, M.C.; Dickson, D.W. Atypical progressive supranuclear palsy with corticospinal tract degeneration. J. Neuropathol. Exp. Neurol. 2006, 65, 396-405. [CrossRef] [PubMed]

11. Williams, D.R. Tauopathies: Classification and clinical update on neurodegenerative diseases associated with microtubule-associated protein tau. Intern. Med. J. 2006, 36, 652-660. [CrossRef] [PubMed]

12. Kovacs, G.G.; Majtenyi, K.; Spina, S.; Murrell, J.R.; Gelpi, E.; Hoftberger, R.; Fraser, G.; Crowther, R.A.; Goedert, M.; Budka, H.; et al. White matter tauopathy with globular glial inclusions: A distinct sporadic frontotemporal lobar degeneration. J. Neuropathol. Exp. Neurol. 2008, 67, 963-975. [CrossRef] [PubMed]

13. Giaccone, G.; Marcon, G.; Mangieri, M.; Morbin, M.; Rossi, G.; Fetoni, V.; Patriarca, C.; Catania, M.; Di Fede, G.; Tagliavini, F.; et al. Atypical tauopathy with massive involvement of the white matter. Neuropathol. Appl. Neurobiol. 2008, 34, 468-472. [PubMed]

14. Ferrer, I.; Santpere, G.; van Leeuwen, F.W. Argyrophilic grain disease. Brain 2008, 146, 1640-1651. [CrossRef] [PubMed]

15. Fu, Y.J.; Nishihira, Y.; Kuroda, S.; Toyoshima, Y.; Ishihara, T.; Shinozaki, M.; Miyashita, A.; Piao, Y.S.; Tan, C.F.; Tani, T.; et al. Sporadic four-repeat tauopathy with frontotemporal lobar degeneration, parkinsonism, and motor neuron disease: A distinct clinicopathological and biochemical disease entity. Acta Neuropathol. 2010, 120, 21-32. [CrossRef] [PubMed]

16. Ahmed, Z.; Doherty, K.M.; Silveira-Moriyama, L.; Bandopadhyay, R.; Lashley, T.; Mamais, A.; Hondhamuni, G.; Wray, S.; Newcombe, J.; O'Sullivan, S.S.; et al. Globular glial tauopathies (GGT) presenting with motor neuron disease or frontotemporal dementia: An emerging group of 4-repeat tauopathies. Acta Neuropathol. 2011, 122, 415-428. [CrossRef] [PubMed]

17. Dickson, D.W.; Hauw, J.J.; Agid, Y.; Litvan, I. Progressive supranuclear palsy and corticobasal degeneration. In Neurodegeneration: The Molecular Pathology of Dementia and Movement Disorders, 2nd ed.; Dickson, D.W., Weller, R.O., Eds.; Willey-Blackwell: Chichester, UK, 2011; pp. 135-155.

18. Muñoz, D.G.; Morris, H.R.; Rossor, M. Pick's disease. In Neurodegeneration: The Molecular Pathology of Dementia and Movement Disorders, 2nd ed.; Dickson, D.W., Weller, R.O., Eds.; Willey-Blackwell: Chichester, UK, 2011; pp. 156-164. 
19. Tolnay, M.; Braak, H. Argyrophilic grain disease. In Neurodegeneration: The Molecular Pathology of Dementia and Movement Disorders, 2nd ed.; Dickson, D.W., Weller, R.O., Eds.; Wiley-Blackwell: Chichester, UK, 2011; pp. 165-170.

20. Ahmed, Z.; Bigio, E.H.; Budka, H.; Dickson, D.W.; Ferrer, I.; Ghetti, B.; Giaccone, G.; Hatanpaa, K.J.; Holton, J.L.; Josephs, K.A.; et al. Globular glial tauopathies (GGT): Consensus recommendations. Acta Neuropathol. 2013, 126, 537-544. [CrossRef] [PubMed]

21. Lowe, J.; Kalaria, R. Dementia. In Greenfield's Neuropathology, 9th ed.; Love, S., Budka, H., Ironside, J., Perry, A., Eds.; CRC Press: Boca Raton, FL, USA, 2015; pp. 858-973.

22. Crary, J.F.; Trojanowski, J.Q.; Schneider, J.A.; Abisambra, J.F.; Abner, E.L.; Alafuzoff, I.; Arnold, S.E.; Attems, J.; Beach, T.G.; Bigio, E.H.; et al. Primary age-related tauopathy (PART): A common pathology associated with human aging. Acta Neuropathol. 2014, 128, 755-766. [CrossRef] [PubMed]

23. Jellinger, K.A.; Alafuzoff, I.; Attems, J.; Beach, T.G.; Cairns, N.J.; Crary, J.F.; Dickson, D.W.; Hof, P.R.; Hyman, B.T.; Jack, C.R., Jr.; et al. PART, a distinct tauopathy, different from classical sporadic Alzheimer disease. Acta Neuropathol. 2015, 129, 757-762. [CrossRef] [PubMed]

24. Kovacs, G.G. Invited review: Neuropathology of tauopathies: Principles and practice. Neuropathol. Appl. Neurobiol. 2015, 41, 3-23. [CrossRef] [PubMed]

25. Kovacs, G.G. Tauopathies. In Neuropathology of Neurodegenerative Diseases: A Practical Guide; Kovacs, G.G., Ed.; Cambridge University Press: Cambridge, UK, 2015; pp. 109-148.

26. Kovacs, G.G.; Ferrer, I.; Grinberg, L.T.; Alafuzoff, I.; Attems, J.; Budka, H.; Cairns, N.J.; Crary, J.F.; Duyckaerts, C.; Ghetti, B.; et al. Aging-related tau astrogliopathy (ARTAG): Harmonized evaluation strategy. Acta Neuropathol. 2016, 131, 87-102. [CrossRef] [PubMed]

27. Graff-Radford, J.; Josephs, K.A.; Parisi, J.E.; Dickson, D.W.; Giannini, C.; Boeve, B.F. Globular glial tauopathy presenting as semantic variant PPA. JAMA Neurol. 2016, 73, 123-125. [CrossRef] [PubMed]

28. Kovacs, G.G.; Lee, V.M.; Trojanowski, J.Q. Protein astrogliopathies in human neurodegenerative diseases and aging. Brain Pathol. 2017, 27, 675-690. [CrossRef] [PubMed]

29. Kovacs, G.G.; Robinson, J.L.; Xie, S.X.; Lee, E.B.; Grossman, M.; Wolk, D.A.; Irwin, D.J.; Weintraub, D.; Kim, C.F.; Schuck, T.; et al. Evaluating the patterns of aging-related tau astrogliopathy unravels novel insights into brain aging and neurodegenerative diseases. J. Neuropathol. Exp. Neurol. 2017, 76, 270-288. [CrossRef] [PubMed]

30. Spillantini, M.G.; Goedert, M.; Crowther, R.A.; Murrell, J.R.; Farlow, M.R.; Ghetti, B. Familial multiple system tauopathy with presenile dementia: A disease with abundant neuronal and glial tau filaments. Proc. Natl. Acad. Sci. USA 1997, 94, 4113-4118. [CrossRef] [PubMed]

31. Iseki, E.; Matsumura, T.; Marui, W.; Hino, H.; Odawara, T.; Sugiyama, N.; Suzuki, K.; Sawada, H.; Arai, T.; Kosaka, K. Familial frontotemporal dementia and parkinsonism with a novel N296H mutation in exon 10 of the tau gene and a widespread tau accumulation in the glial cells. Acta Neuropathol. 2001, 102, 285-292. [PubMed]

32. Spina, S.; Farlow, M.R.; Unverzagt, F.W.; Kareken, D.A.; Murrell, J.R.; Fraser, G.; Epperson, F.; Crowther, R.A.; Spillantini, M.G.; Goedert, M.; et al. The tauopathy associated with mutation +3 in intron 10 of tau: Characterization of the MSTD family. Brain 2008, 131, 72-89. [CrossRef] [PubMed]

33. Ghetti, B.; Wszolek, Z.K.; Boeve, B.F.; Spina, S.; Goedert, M. Frontotemporal dementia and parkinsonism linked to chromosome 17. In Neurodegeneration: The Molecular Pathology of Dementia and Movement Disorders, 2nd ed.; Dickson, D.W., Weller, R.O., Eds.; Willey-Blackwell: Chichester, UK, 2011; pp. 110-134.

34. Tacik, P.; Sanchez-Contreras, M.; Rademakers, R.; Dickson, D.W.; Wszolek, Z.K. Genetic disorders with tau pathology: A review of the literature and report of two patients with tauopathy and positive family histories. Neurodegener. Dis. 2016, 16, 12-21. [CrossRef] [PubMed]

35. Tacik, P.; DeTure, M.; Lin, W.L.; Sanchez-Contreras, M.; Wojtas, A.; Hinkle, K.M.; Fujioka, S.; Baker, M.C.; Walton, R.L.; Carlomagno, Y.; et al. A novel tau mutation, p.K317N, causes globular glial tauopathy. Acta Neuropathol. 2015, 130, 199-214. [CrossRef] [PubMed]

36. Zarranz, J.J.; Ferrer, I.; Lezcano, E.; Forcadas, M.I.; Eizaguirre, B.; Atares, B.; Puig, B.; Gomez-Esteban, J.C.; Fernandez-Maiztegui, C.; Rouco, I.; et al. A novel mutation (K317M) in the MAPT gene causes FTDP and motor neuron disease. Neurology 2005, 64, 1578-1585. [CrossRef] [PubMed] 
37. Ferrer, I.; López-González, I.; Carmona, M.; Arregui, L.; Dalfó, E.; Torrejón-Escribano, B.; Diehl, R.; Kovacs, G.G. Glial and neuronal tau pathology in tauopathies: Characterization of disease-specific phenotypes and tau pathology progression. J. Neuropathol. Exp. Neurol. 2014, 73, 81-97. [CrossRef] [PubMed]

38. Borrego-Écija, S.; Morgado, J.; Palencia-Madrid, L.; Grau-Rivera, O.; Reñé, R.; Hernández, I.; Almenar, C.; Balasa, M.; Antonell, A.; Molinuevo, J.L.; et al. Frontotemporal dementia caused by the P301L mutation in the MAPT gene: Clinicopathological features of 13 cases from the same geographical origin in Barcelona, Spain. Dement. Geriatr. Cogn. Disord. 2017, 44, 213-221. [CrossRef] [PubMed]

39. Duyckaerts, C.; Dickson, D. Neuropathology of Alzheimer's disease. In Neurodegeneration: The Molecular Pathology of Dementia and Movement Disorders, 2nd ed.; Dickson, D.W., Weller, R.O., Eds.; Willey-Blackwell: Chichester, UK, 2011; pp. 62-91.

40. Revesz, T.; Rostagno, A.; Plant, G.; Lashley, T.; Frangione, B.; Ghiso, J.; Holton, J.L. Inherited amyloidoses and neurodegeneration: Familial British dementia and Familial Danish dementia. In Neurodegeneration: The Molecular Pathology of Dementia and Movement Disorders, 2nd ed.; Dickson, D.W., Weller, R.O., Eds.; Willey-Blackwell: Chichester, UK, 2011; pp. 439-445.

41. Ghetti, B.; Tagliavini, F.; Kovacs, G.G.; Piccardo, P. Gerstmann-Straüssler-Scheinker. In Neurodegeneration: The Molecular Pathology of Dementia and Movement Disorders, 2nd ed.; Dickson, D.W., Weller, R.O., Eds.; Willey-Blackwell: Chichester, UK, 2011; pp. 364-377.

42. Rahimi, J.; Kovacs, G.G. Prevalence of mixed pathologies in the aging brain. Alzheimer's Res. Ther. $2014,6,82$. [CrossRef] [PubMed]

43. Thal, D.R.; von Arnim, C.A.; Griffin, W.S.; Mrak, R.E.; Walker, L.; Attems, J.; Arzberger, T. Frontotemporal lobar degeneration FTLD-tau: Preclinical lesions, vascular, and Alzheimer-related co-pathologies. J. Neural Transm. 2015, 122, 1007-1018. [CrossRef] [PubMed]

44. Oikawa, N.; Kimura, N.; Yanagisawa, K. Alzheimer-type tau pathology in advanced aged nonhuman primate brains harboring substantial amyloid deposition. Brain Res. 2010, 1315, 137-149. [CrossRef] [PubMed]

45. Perez, S.E.; Raghanti, M.A.; Hof, P.R.; Kramer, L.; Ikonomovic, M.D.; Lacor, P.N.; Erwin, J.M.; Sherwood, C.C.; Mufson, E.J. Alzheimer's disease pathology in the neocortex and hippocampus of the western lowland gorilla (Gorilla gorilla gorilla). J. Comp. Neurol. 2013, 521, 4318-4338. [CrossRef] [PubMed]

46. Perez, S.E.; Sherwood, C.C.; Cranfield, M.R.; Erwin, J.M.; Mudakikwa, A.; Hof, P.R.; Mufson, E.J. Early Alzheimer's disease-type pathology in the frontal cortex of wild mountain gorillas (Gorilla beringei beringei). Neurobiol. Aging 2016, 39, 195-201. [CrossRef] [PubMed]

47. Schultz, C.; Dehghani, F.; Hubbard, G.B.; Thal, D.R.; Struckhoff, G.; Braak, E.; Braak, H. Filamentous tau pathology in nerve cells, astrocytes, and oligodendrocytes of aged baboons. J. Neuropathol. Exp. Neurol. 2000, 59, 39-52. [CrossRef] [PubMed]

48. Rosen, R.F.; Farberg, A.S.; Gearing, M.; Dooyema, J.; Long, P.M.; Anderson, D.C.; Davis-Turak, J.; Coppola, G.; Geschwind, D.H.; Paré, J.F.; et al. Tauopathy with paired helical filaments in an aged chimpanzee. J. Comp. Neurol. 2008, 509, 259-270. [CrossRef] [PubMed]

49. Edler, M.K.; Sherwood, C.C.; Meindl, R.S.; Hopkins, W.D.; Ely, J.J.; Erwin, J.M.; Mufson, E.J.; Hof, P.R.; Raghanti, M.A. Aged chimpanzees exhibit pathologic hallmarks of Alzheimer's disease. Neurobiol. Aging 2017, 59, 107-120. [CrossRef] [PubMed]

50. Lemere, C.A.; Oh, J.; Stanish, H.A.; Peng, Y.; Pepivani, I.; Fagan, A.M.; Yamaguchi, H.; Westmoreland, S.V.; Mansfield, K.G. Cerebral amyloid- $\beta$ protein accumulation with aging in cotton-top tamarins: A model of early Alzheimer's disease? Rejuvenation Res. 2008, 11, 321-332. [CrossRef] [PubMed]

51. Holzer, M.; Craxton, M.; Jakes, R.; Arendt, T.; Goedert, M. Tau gene (MAPT) sequence variation among primates. Gene 2004, 341, 313-322. [CrossRef] [PubMed]

52. Nishimura, M.; Namba, Y.; Ikeda, K.; Oda, M. Glial fibrillary tangles with straight tubules in the brains of patients with progressive supranuclear palsy. Neurosci. Lett. 1992, 143, 35-38. [CrossRef]

53. Yamada, T.; McGeer, P.L.; McGeer, E.G. Appearance of paired nucleated, tau-positive glia in patients with progressive supranuclear palsy brain tissue. Neurosci. Lett. 1992, 135, 99-102. [CrossRef]

54. Nishimura, T.; Ikeda, K.; Akiyama, H.; Kondo, H.; Kato, M.; Li, F.; Iseki, E.; Kosaka, K. Immunohistochemical investigation of tau-positive structures in the cerebral cortex of patients with progressive supranuclear palsy. Neurosci. Lett. 1995, 201, 123-126. [CrossRef]

55. Feany, M.B.; Dickson, D.W. Widespread cytoskeletal pathology characterizes corticobasal degeneration. Am. J. Pathol. 1995, 146, 1388-1396. [PubMed] 
56. Ikeda, K.; Akiyama, H.; Arai, T.; Nishimura, T. Glial tau pathology in neurodegenerative diseases: Their nature and comparison with neuronal tangles. Neurobiol. Aging 1998, 19 (Suppl. 1), S85-S91. [CrossRef]

57. Komori, T.; Arai, N.; Oda, M.; Nakayama, H.; Mori, H.; Yagishita, S.; Takahashi, T.; Amano, N.; Murayama, S.; Murakami, S.; et al. Astrocytic plaques and tufts of abnormal fibers do not coexist in corticobasal degeneration and progressive supranuclear palsy. Acta Neuropathol. 1998, 96, 401-408. [CrossRef] [PubMed]

58. Komori, T. Tau-positive glial inclusions in progressive supranuclear palsy, corticobasal degeneration and Pick's disease. Brain Pathol. 1999, 9, 663-679. [CrossRef] [PubMed]

59. Arai, T.; Ikeda, K.; Akiyama, H.; Shikamoto, Y.; Tsuchiya, K.; Yagishita, S.; Beach, T.; Rogers, J.; Schwab, C.; McGeer, P.L. Distinct isoforms of tau aggregated in neurons and glial cells in brains of patients with Pick's disease, corticobasal degeneration and progressive supranuclear palsy. Acta Neuropathol. 2001, 101, 167-173. [PubMed]

60. Arai, T.; Ikeda, K.; Akiyama, H.; Tsuchiya, K.; Yagishita, S.; Takamatsu, J. Intracellular processing of aggregated tau differs between corticobasal degeneration and progressive supranuclear palsy. Neuroreport 2001, 12, 935-938. [CrossRef] [PubMed]

61. Hattori, M.; Hashizume, Y.; Yoshida, M.; Iwasaki, Y.; Hishikawa, N.; Ueda, R.; Ojika, K. Distribution of astrocytic plaques in the corticobasal degeneration brain and comparison with tuft-shaped astrocytes in the progressive supranuclear palsy brain. Acta Neuropathol. 2003, 106, 143-149. [CrossRef] [PubMed]

62. Iwasaki, Y.; Yoshida, M.; Hattori, M.; Goto, A.; Aiba, I.; Hashizume, Y.; Sobue, G. Distribution of tuft-shaped astrocytes in the cerebral cortex in progressive supranuclear palsy. Acta Neuropathol. 2004, 108, 399-405. [CrossRef] [PubMed]

63. Arima, K. Ultrastructural characteristics of tau filaments in tauopathies: Immuno-electron microscopic demonstration of tau filaments in tauopathies. Neuropathology 2006, 26, 475-483. [CrossRef] [PubMed]

64. Mimuro, M.; Yoshida, M.; Miyao, S.; Harada, T.; Ishiguro, K.; Hashizume, Y. Neuronal and glial tau pathology in early frontotemporal lobar degeneration-tau, Pick's disease subtype. J. Neurol. Sci. 2010, 290, 177-182. [CrossRef] [PubMed]

65. Yoshida, M. Astrocytic inclusions in progressive supranuclear palsy and corticobasal degeneration. Neuropathology 2014, 34, 555-570. [CrossRef] [PubMed]

66. Ghetti, B.; Oblak, A.L.; Boeve, B.F.; Johnson, K.A.; Dickerson, B.C.; Goedert, M. Invited review: Frontotemporal dementia caused by microtubule-associated protein tau gene (MAPT) mutations: A chameleon for neuropathology and neuroimaging. Neuropathol. Appl. Neurobiol. 2015, 41, 24-46. [CrossRef] [PubMed]

67. Ikeda, K.; Akiyama, H.; Kondo, H.; Haga, C.; Tanno, E.; Tokuda, T.; Ikeda, S. Thorn-shaped astrocytes: Possibly secondarily induced tau-positive glial fibrillary tangles. Acta Neuropathol. 1995, 90, 620-625. [CrossRef] [PubMed]

68. Schultz, C.; Ghebremedhin, E.; Del Tredici, K.; Rüb, U.; Braak, H. High prevalence of thorn-shaped astrocytes in the aged human medial temporal lobe. Neurobiol. Aging 2004, 25, 397-405. [CrossRef]

69. Muñoz, D.G.; Woulfe, J.; Kertesz, A. Argyrophilic thorny astrocyte clusters in association with Alzheimer's disease pathology in possible primary progressive aphasia. Acta Neuropathol. 2007, 114, 347-357. [CrossRef] [PubMed]

70. Kovacs, G.G.; Molnár, K.; László, L.; Ströbel, T.; Botond, G.; Hönigschnabl, S.; Reiner-Concin, A.; Palkovits, M.; Fischer, P.; Budka, H. A peculiar constellation of tau pathology defines a subset of dementia in the elderly. Acta Neuropathol. 2011, 122, 205-222. [CrossRef] [PubMed]

71. López-González, I.; Carmona, M.; Blanco, R.; Luna-Muñoz, J.; Martínez-Mandonado, A.; Mena, R.; Ferrer, I. Characterization of thorn-shaped astrocytes in white matter of temporal lobe in Alzheimer's disease brains. Brain Pathol. 2013, 23, 144-153. [CrossRef] [PubMed]

72. Liu, A.K.; Goldfinger, M.H.; Questari, H.E.; Pearce, R.K.; Gentleman, S.M. ARTAG in the basal forebrain: Widening the constellation of astrocytic tau pathology. Acta Neuropathol. Commun. 2016, 4, 59. [CrossRef] [PubMed]

73. Lingh, H.; Neal, J.W.; Revesz, T. Evolving concepts of chronic traumatic encephalopathy as a neuropathklogical entity. Neuropathol. Appl. Neurobiol. 2017, 43, 467-476. [CrossRef] [PubMed]

74. Santpere, G.; Ferrer, I. Delineation of early changes in cases with progressive supranuclear palsy-like pathology. Astrocytes in striatum are primary targets of tau phosphorylation and GFAP oxidation. Brain Pathol. 2009, 19, 177-187. [CrossRef] [PubMed] 
75. Ling, H.; Kovacs, G.G.; Vonsattel, J.P.; Davey, K.; Mok, K.Y.; Hardy, J.; Morris, H.R.; Warner, T.T.; Holton, J.L.; Revesz, T. Astrogliopathy predominates the earliest stage of corticobasal degeneration pathology. Brain 2016, 139, 3237-3252. [CrossRef] [PubMed]

76. Martinez-Maldonado, A.; Luna-Munoz, J.; Ferrer, I. Incidental corticobasal degeneration. Neuropathol. Appl. Neurobiol. 2016, 42, 659-663. [CrossRef] [PubMed]

77. Iijima, M.; Tabira, T.; Poorkaj, P.; Schellenberg, G.D.; Trojanowski, J.Q.; Lee, V.M.; Schmidt, M.L.; Takahashi, K.; Nabika, T.; Matsumoto, T.; et al. A distinct familial presenile dementia with a novel missense mutation in the tau gene. Neuroreport 1999, 10, 497-501. [CrossRef] [PubMed]

78. Stanford, P.M.; Halliday, G.M.; Brooks, W.S.; Kwok, J.B.; Storey, C.E.; Creasey, H.; Morris, J.G.; Fulham, M.J.; Schofield, P.R. Progressive supranuclear palsy pathology caused by a novel silent mutation in exon 10 of the tau gene: Expansion of the disease phenotype caused by tau gene mutations. Brain 2000, 123, 880-893. [CrossRef] [PubMed]

79. Hayashi, S.; Toyoshima, Y.; Hasegawa, M.; Umeda, Y.; Wakabayashi, K.; Tokiguchi, S.; Iwatsubo, T.; Takahashi, H. Late-onset frontotemporal dementia with a novel exon 1 (Arg5His) tau gene mutation. Ann. Neurol. 2002, 51, 525-530. [CrossRef] [PubMed]

80. Poorkaj, P.; Muma, N.A.; Zhukareva, V.; Cochran, E.J.; Shannon, K.M.; Hurtig, H.; Koller, W.C.; Bird, T.D.; Trojanowski, J.Q.; Lee, V.M.; et al. An R5L tau mutation in a subject with a progressive supranuclear palsy phenotype. Ann. Neurol. 2002, 52, 511-516. [CrossRef] [PubMed]

81. Kobayashi, T.; Ota, S.; Tanaka, K.; Ito, Y.; Hasegawa, M.; Umeda, Y.; Motoi, Y.; Takanashi, M.; Yasuhara, M.; Anno, M.; et al. A novel L266V mutation of the tau gene causes frontotemporal dementia with a unique tau pathology. Ann. Neurol. 2003, 53, 133-137. [CrossRef] [PubMed]

82. Ferrer, I.; Pastor, P.; Rey, M.J.; Muñoz, E.; Puig, B.; Pastor, E.; Oliva, R.; Tolosa, E. Tau phosphorylation and kinase activation in familial tauopathy linked to deln296 mutation. Neuropathol. Appl. Neurobiol. 2003, 29, 23-34. [CrossRef] [PubMed]

83. Van Herpen, E.; Rosso, S.M.; Serverijnen, L.A.; Yoshida, H.; Breedveld, G.; van de Graaf, R.; Kamphorst, W.; Ravid, R.; Willemsen, R.; Dooijes, D.; et al. Variable phenotypic expression and extensive tau pathology in two families with the novel tau mutation L315R. Ann. Neurol. 2003, 54, 573-581. [CrossRef] [PubMed]

84. Halliday, G.M.; Song, Y.J.; Creasey, H.; Morris, J.G.; Brooks, W.S.; Kril, J.J. Neuropathology in the S305S tau gene mutation. Brain 2006, 129, E40. [CrossRef] [PubMed]

85. Ros, R.; Thobois, S.; Streichenberger, N.; Kopp, N.; Sanchez, M.P.; Perez, M.; Hoenicka, J.; Avila, J.; Honnorat, J.; de Yébenes, J.G. A new mutation of the tau gene, G303V, in early-onset familial progressive supranuclear palsy. Arch. Neurol. 2005, 62, 1444-1450. [CrossRef] [PubMed]

86. Malkani, R.; D'Souza, I.; Gwinn-Hardy, K.; Schellenberg, G.D.; Hardy, J.; Momeni, P. A MAPT mutation in a regulatory element upstream of exon 10 causes frontotemporal dementia. Neurobiol. Dis. 2006, 22, 401-403. [CrossRef] [PubMed]

87. Ferrer, I.; Legati, A.; García-Monco, J.C.; Gomez-Beldarrain, M.; Carmona, M.; Blanco, R.; Seeley, W.W.; Coppola, G. Familial behavioral variant frontotemporal dementia associated with astrocyte-predominant tauopathy. J. Neuropathol. Exp. Neurol. 2015, 74, 370-379. [CrossRef] [PubMed]

88. Botez, G.; Probst, A.; Ipsen, S.; Tolnay, M. Astrocytes expressing hyperphosphorylated tau protein without glial fibrillary tangles in argyrophilicgrain disease. Acta Neuropathol. 1999, 98, 251-256. [CrossRef] [PubMed]

89. Armstrong, R.A.; Cairns, N.J. Spatial patterns of the tau pathology in progressive supranuclear palsy. Neurol. Sci. 2013, 34, 337-344. [CrossRef] [PubMed]

90. Milenkovic, I.; Kovacs, G.G. Incidental corticobasal degeneration in a 76-year-old woman. Clin. Neuropathol. 2013, 32, 69-72. [CrossRef] [PubMed]

91. Irwin, D.J.; Brettschneider, J.; McMillan, C.T.; Cooper, F.; Olm, C.; Arnold, S.E.; van Deerlin, V.M.; Seeley, W.W.; Miller, B.L.; Lee, E.B.; et al. Deep clinical and neuropathological phenotyping of Pick disease. Ann. Neurol. 2016, 79, 272-287. [CrossRef] [PubMed]

92. Ferrer, I. Diversity of astroglial responses across human neurodegenerative disorders and brain aging. Brain Pathol. 2017, 27, 645-674. [CrossRef] [PubMed]

93. Shibuya, K.; Yagishita, S.; Nakamura, A.; Uchihara, T. Perivascular orientation of astrocytic plaques and tuft-shaped astrocytes. Brain Res. 2011, 1404, 50-54. [CrossRef] [PubMed] 
94. Higuchi, M.; Ishihara, T.; Zhang, B.; Hong, M.; Andreadis, A.; Trojanowski, J.; Lee, V.M. Transgenic mouse model of tauopathies with glial pathology and nervous system degeneration. Neuron 2002, 35, 433-446. [CrossRef]

95. Lin, W.L.; Lewis, J.; Yen, S.H.; Hutton, M.; Dickson, D.W. Filamentous tau oligodendrocytes and astrocytes of transgenic mice expressing the human tau isoform with the P301L mutation. Am. J. Pathol. 2003, 162, 213-218. [CrossRef]

96. Atzori, C.; Ghetti, B.; Piva, R.; Srinivasan, A.N.; Zolo, P.; Delisle, M.B.; Mirra, S.S.; Migheli, A. Activation of the JNK/p38 pathway occurs in diseases characterized by tau protein pathology and is related to tau phosphorylation but not to apoptosis. J. Neuropathol. Exp. Neurol. 2001, 60, 1190-1197. [CrossRef] [PubMed]

97. Ferrer, I.; Blanco, R.; Carmona, M.; Puig, B. Phosphorylated mitogen-activated protein kinase (MAPK/ERK-P), protein kinase of $38 \mathrm{kDa}(\mathrm{p} 38-\mathrm{P})$, stress-activated protein kinase (SAPK/JNK-P), and calcium/calmodulin-dependent kinase II (CaM kinase II) are differentially expressed in tau deposits in neurons and glial cells in tauopathies. J. Neural Transm. 2001, 108, 1397-1415. [PubMed]

98. Ferrer, I.; Blanco, R.; Carmona, M.; Ribera, R.; Goutan, E.; Puig, B.; Rey, M.J.; Cardozo, A.; Viñals, F.; Ribalta, T. Phosphorylated map kinase (ERK1, ERK2) expression is associated with early tau deposition in neurones and glial cells, but not with increased nuclear DNA vulnerability and cell death, in Alzheimer disease, Pick's disease, progressive supranuclear palsy and corticobasal degeneration. Brain Pathol. 2001, 11, 144-158. [PubMed]

99. Ferrer, I.; Barrachina, M.; Puig, B. Glycogen synthase kinase-3 is associated with neuronal and glial hyperphosphorylated tau deposits in Alzheimer's disease, Pick's disease, progressive supranuclear palsy and corticobasal degeneration. Acta Neuropathol. 2002, 104, 583-591. [PubMed]

100. Ferrer, I.; Barrachina, M.; Tolnay, M.; Rey, M.J.; Vidal, N.; Carmona, M.; Blanco, R.; Puig, B. Phosphorylated protein kinases associated with neuronal and glial tau deposits in argyrophilic grain disease. Brain Pathol. 2003, 13, 62-78. [CrossRef] [PubMed]

101. Nishimura, T.; Ikeda, K.; Akiyama, H.; Arai, T.; Kondo, H.; Okochi, M.; Furiya, Y.; Mori, H.; Oda, T.; Kato, M.; et al. Glial tau-positive structures lack the sequence encoded by exon 3 of the tau protein gene. Neurosci. Lett. 1997, 224, 169-172. [CrossRef]

102. Irwin, D.J.; Cohen, T.J.; Grossman, M.; Arnold, S.E.; McCarty-Wood, E.; Van Deerlin, V.M.; Lee, V.M.; Trojanowski, J.Q. Acetylated tau neuropathology in sporadic and hereditary tauopathies. Am. J. Pathol. 2013, 183, 344-351. [CrossRef] [PubMed]

103. Grinberg, L.T.; Wang, X.; Wang, C.; Sohn, P.D.; Theofilas, P.; Sidhu, M.; Arevalo, J.B.; Heinsen, H.; Huang, E.J.; Rosen, H.; et al. Argyrophilic grain disease differs from other tauopathies by lacking tau acetylation. Acta Neuropathol. 2013, 125, 581-593. [CrossRef] [PubMed]

104. Min, S.W.; Cho, S.H.; Zhou, Y.; Schroeder, S.; Haroutunian, V.; Seeley, W.W.; Huang, E.J.; Shen, Y.; Masliah, E.; Mukherjee, C.; et al. Acetylation of tau inhibits its degradation and contributes to tauopathy. Neuron 2010, 67, 953-966. [CrossRef] [PubMed]

105. Cohen, T.J.; Guo, J.L.; Hurtado, D.E.; Kwong, L.K.; Mills, I.P.; Trojanowski, J.Q.; Lee, V.M. The acetylation of tau inhibits its function and promotes pathological tau aggregation. Nat. Commun. 2011, 2, 252. [CrossRef] [PubMed]

106. Ferrer, I.; Aguiló García, M.; López González, I.; Diaz Lucena, D.; Roig Villalonga, A.; Carmona, M.; Llorens, F.; Garcia-Esparcia, P.; Martinez-Maldonado, A.; Frau Mendez, M.; et al. Aging-related tau astrogliopathy (ARTAG): Not only tau phosphorylation in astrocytes. Brain Pathol. 2018. [CrossRef] [PubMed]

107. Kimmelberg, H.K. The problem of astrocyte identity. Neurochem. Int. 2004, 45, 191-202. [CrossRef] [PubMed]

108. Sofroniew, M.V.; Vinters, H.V. Astrocytes: Biology and pathology. Acta Neuropathol. 2010, 119, 7-35. [CrossRef] [PubMed]

109. Chandrasekaran, A.; Avci, H.X.; Leist, M.; Kobolák, J.; Dinnyés, A. Astrocyte differentiation of human pluripotent stem cells: New tolos for neurological disorder research. Front. Cell. Neurosci. 2016, 10, 215. [CrossRef] [PubMed]

110. Oberheim, N.A.; Goldman, S.A.; Nedergaard, M. Heterogeneity of astrocytic form and function. Methods Mol. Biol. 2012, 814, 23-45. [PubMed]

111. Song, Y.J.; Halliday, G.M.; Holton, J.L.; Lashley, T.; O’Sullivan, S.S.; McCann, H.; Lees, A.J.; Ozawa, T.; Williams, D.R.; Lockhart, P.J.; et al. Degeneration in different parkinsonian syndromes relates to astrocyte type and astrocyte protein expression. J. Neuropathol. Exp. Neurol. 2009, 68, 1073-1083. [CrossRef] [PubMed] 
112. Pekny, M.; Nilsson, M. Astrocyte activation and reactive gliosis. Glia 2005, 50, 427-434. [CrossRef] [PubMed]

113. Seifert, G.; Schilling, K.; Steinhauser, C. Astrocyte dysfunction in neurological disorders: A molecular perspective. Nat. Rev. Neurosci. 2006, 7, 194-206. [CrossRef] [PubMed]

114. Verkhratsky, A.; Rodríguez, J.J.; Parpura, V. Astroglia in neurological diseases. Future Neurol. 2013, 8, $149-158$. [CrossRef] [PubMed]

115. Verkhratsky, A.; Rodríguez, J.J.; Parpura, V. Neuroglia in ageing and disease. Cell Tissue Res. 2014, 357, 493-503. [CrossRef] [PubMed]

116. Verkhratsky, A.; Zorec, R.; Rodriguez, J.J.; Parpura, V. Astroglia dynamics in ageing and Alzheimer's disease. Curr. Opin. Pharmacol. 2016, 26, 74-79. [CrossRef] [PubMed]

117. Pekny, M.; Pekna, M. Astrocyte reactivity and reactive astrogliosis: Costs and benefits. Physiol. Rev. 2014, 94, 1077-1098. [CrossRef] [PubMed]

118. Pekny, M.; Pekna, M. Reactive gliosis in the pathogenesis of CNS diseases. Biochim. Biophys. Acta 2016, 1862, 483-491. [CrossRef] [PubMed]

119. Verkhratsky, A.; Zorec, R.; Parpura, V. Stratification of astrocytes in healthy and diseased brain. Brain Pathol. 2017, 27, 629-644. [CrossRef] [PubMed]

120. Verkhratsky, A.; Zorec, R.; Rodriguez, J.J.; Parpura, V. Neuroglia: Functional paralysis and reactivity in Alzheimer's disease and other neurodegenerative pathologies. Adv. Neurobiol. 2017, 15, 427-449. [PubMed]

121. Osborn, L.M.; Kamphuis, W.; Wadman, W.J.; Hol, E.M. Astrogliosis: An integral player in the pathogenesis of Alzheimer's disease. Prog. Neurobiol. 2016, 144, 121-141. [CrossRef] [PubMed]

122. Pekny, M.; Pekna, M.; Messing, A.; Steinhäuser, C.; Lee, J.M.; Parpura, V.; Hol, E.M.; Sofroniew, M.V.; Verkhratsky, A. Astrocytes: A central element in neurological diseases. Acta Neuropathol. 2016, 131, 323-345. [CrossRef] [PubMed]

123. Kersaitis, C.; Halliday, G.M.; Kril, J.J. Regional and cellular pathology in frontotemporal dementia: Relationship to stage of disease in cases with and without Pick bodies. Acta Neuropathol. 2004, 108, 515-523. [CrossRef] [PubMed]

124. Togo, T.; Dickson, D.W. Tau accumulation in astrocytes in progressive supranuclear palsy is a degenerative rather than a reactive process. Acta Neuropathol. 2002, 104, 398-402. [PubMed]

125. López-González, I.; Aso, E.; Carmona, M.; Armand-Ugon, M.; Blanco, R.; Naudí, A.; Cabré, R.; Portero-Otin, M.; Pamplona, R.; Ferrer, I. Neuroinflammatory gene regulation, mitochondrial function, oxidative stress, and brain lipid modifications with disease progression in Tau P301S transgenic mice as a model of frontotemporal lobar degeneration-Tau. J. Neuropathol. Exp. Neurol. 2015, 74, 975-999. [CrossRef] [PubMed]

126. Renkawek, K.; Bosman, G.J.; de Jong, W.W. Expression of small heat-shock protein Hsp27 in reactive gliosis in Alzheimer disease and other types of dementia. Acta Neuropathol. 1994, 87, 511-519. [CrossRef] [PubMed]

127. Dabir, D.V.; Trojanowski, J.Q.; Richter-Landsberg, C.; Lee, V.M.; Forman, M.S. Expression of the small heat-shock protein $\alpha$ B-crystallin in tauopathies with glial pathology. Am. J. Pathol. 2004, 164, 155-166. [CrossRef]

128. Schwarz, L.; Vollmer, G.; Richter-Landsberg, C. The small heat shock protein HSP25/27 (HspB1) is abundant in cultured astrocytes and associated with astrocytic pathology in progressive supranuclear palsy and corticobasal degeneration. Int. J. Cell Biol. 2010, 2010, 717520. [CrossRef] [PubMed]

129. López-González, I.; Carmona, M.; Arregui, L.; Kovacs, G.G.; Ferrer, I. $\alpha$ B-crystallin and HSP27 in glial cells in tauopathies. Neuropathology 2014, 34, 517-526. [CrossRef] [PubMed]

130. Filipcik, P.; Cente, M.; Zilka, N.; Smolek, T.; Hanes, J.; Kucerak, J.; Opattova, A.; Kovacech, B.; Novak, M. Intraneuronal accumulation of misfolded tau protein induces overexpression of Hsp27 in activated astrocytes. Biochim. Biophys. Acta 2015, 1852, 1219-1229. [CrossRef] [PubMed]

131. Kahlson, M.A.; Colodner, K.J. Glial tau pathology in tauopathies: Functional consequences. J. Exp. Neurosci. 2016, 9, 43-50. [CrossRef] [PubMed]

132. Verkhratsky, A.; Nedergaard, M. Physiology of astroglia. Physiol. Rev. 2018, 98, 239-389. [CrossRef] [PubMed]

133. Cahoy, J.D.; Emery, B.; Kaushal, A.; Foo, L.C.; Zamanian, J.L.; Christopherson, K.S.; Xing, Y.; Lubischer, J.L.; Krieg, P.A.; Krupenko, S.A.; et al. A transcriptome database for astrocytes, neurons, and oligodendrocytes: A new resource for understanding brain development and function. J. Neurosci. 2008, 28, 264-278. [CrossRef] [PubMed] 
134. Orre, M.; Kamphuis, W.; Osborn, L.M.; Melief, J.; Kooijman, L.; Huitinga, I.; Klooster, J.; Bossers, K.; Hol, E.M. Acute isolation and transcriptome characterization of cortical astrocytes and microglia from young and aged mice. Neurobiol. Aging 2014, 35, 1-14. [CrossRef] [PubMed]

135. Darmanis, S.; Sloan, S.A.; Zhang, Y.; Enge, M.; Caneda, C.; Shuer, L.M.; Gephart, M.G.H.; Barres, B.A.; Quake, S.R. A survey of human brain transcriptome diversity at the single cell level. PNAS 2015, 112, 7285-7290. [CrossRef] [PubMed]

136. Zeisel, A.; Muñoz-Manchado, A.B.; Codeluppi, S.; Lönnerberg, P.; La Manno, G.; Juréus, A.; Marques, S.; Munguba, H.; He, L.; Betsholtz, C.; et al. Brain structure. Cell types in the mouse cortex and hippocampus revealed by single-cell RNA-seq. Science 2015, 347, 1138-1142. [CrossRef] [PubMed]

137. Zhang, Y.; Sloan, S.A.; Clarke, L.E.; Caneda, C.; Plaza, C.A.; Blumenthal, P.D.; Vogel, H.; Steinberg, G.K.; Edwards, M.S.; Li, G.; et al. Purification and characterization of progenitor and mature human astrocytes reveals transcriptional and functional differences in mouse. Neuron 2016, 89, 37-53. [CrossRef] [PubMed]

138. Lin, C.C.J.; Yu, K.; Hatcher, A.; Huang, T.W.; Lee, H.K.; Carlson, J.; Weston, M.C.; Chen, F.; Zhang, Y.; $\mathrm{Zhu}, \mathrm{W}$.; et al. Identification of diverse astrocyte populations and their malignant analogs. Nat. Neurosci. 2017, 20, 396-405.

139. Habib, N.; Avraham-Davidi, I.; Basu, A.; Burks, T.; Shekhar, K.; Hofree, M.; Choudhury, S.R.; Aguet, F.; Gelfand, E.; Ardlie, K.; et al. Massively parallel single-nucleus RNA-seq with Dronc-seq. Nat. Methods 2017, 14, 955-958. [CrossRef] [PubMed]

140. Spaethling, J.M.; Na, Y.-J.; Lee, J.; Ulyanova, A.V.; Baltuch, G.H.; Bell, T.J.; Brem, S.; Chen, H.I.; Dueck, H.; Fisher, S.A.; et al. Primary cell culture of live neurosurgically-resected aged adult human brain cells and single cell transcriptomics. Cell Rep. 2017, 18, 791-803. [CrossRef] [PubMed]

141. Simpson, J.E.; Ince, P.G.; Shaw, P.J.; Heath, P.R.; Raman, R.; Garwood, C.J.; Gelsthorpe, C.; Baxter, L.; Forster, G.; Matthews, F.E.; et al. Microarray analysis of the astrocyte transcriptome in the aging brain: Relationship to Alzheimer's pathology and APOE genotype. Neurobiol. Aging 2011, 32, 1795-1807. [CrossRef] [PubMed]

142. Orre, M.; Kamphuis, W.; Osborn, L.M.; Jansen, A.H.; Kooijman, L.; Bossers, K.; Hol, E.M. Isolation of glia from Alzheimer's mice reveals inflammation and dysfunction. Neurobiol. Aging 2014, 35, 2746-2760. [CrossRef] [PubMed]

143. Yoshiyama, Y.; Zhang, B.; Bruce, J.; Trojanowski, J.Q.; Lee, V.M. Reduction of detyrosinated microtubules and Golgi fragmentation are linked to tau-induced degeneration in astrocytes. J. Neurosci. 2003, 23, 10662-10671. [CrossRef] [PubMed]

144. Colodner, K.J.; Feany, M.B. Glial fibrillary tangles and JAK/STAT-mediated glial and neuronal cell death in a Drosophila model of glial tauopathy. J. Neurosci. 2010, 30, 16102-16113. [CrossRef] [PubMed]

145. Ke, Y.D.; Dramiga, J.; Schütz, U.; Kril, J.J.; Ittner, L.M.; Schröder, H.; Götz, J. Tau-mediated nuclear depletion and cytoplasmic accumulation of SFPQ in Alzheimer's and Pick's disease. PLoS ONE 2012, 7, E35678. [CrossRef]

146. Frost, B.; Hemberg, M.; Lewis, J.; Feany, M.B. Tau promotes neurodegeneration through global chromatin relaxation. Nat. Neurosci. 2014, 17, 357-366. [CrossRef] [PubMed]

147. Hernández-Ortega, K.; Garcia-Esparcia, P.; Gil, L.; Lucas, J.J.; Ferrer, I. Altered machinery of protein synthesis in Alzheimer's: From the nucleolus to the ribosome. Brain Pathol. 2016, 26, 593-605. [CrossRef] [PubMed]

148. Forman, M.S.; Lal, D.; Zhang, B.; Dabir, D.V.; Swanson, E.; Lee, V.M.; Trojanowski, J.Q. Transgenic mouse model of tau pathology in astrocytes leading to nervous system degeneration. J. Neurosci. 2005, 25, 3539-3550. [CrossRef] [PubMed]

149. Dabir, D.V.; Robinson, M.B.; Swanson, E.; Zhang, B.; Trojanowski, J.Q.; Lee, V.M.; Forman, M.S. Impaired glutamate transport in a mouse model of tau pathology in astrocytes. J. Neurosci. 2006, 26, 644-654. [CrossRef] [PubMed]

150. Piacentini, R.; Li Puma, D.D.; Mainardi, M.; Lazzarino, G.; Tavazzi, B.; Arancio, O.; Grassi, C. Reduced gliotransmitter release from astrocytes mediates tau-induced synaptic dysfunction in cultured hippocampal neurons. Glia 2017, 65, 1302-1316. [CrossRef] [PubMed]

151. Hallmann, A.L.; Araúzo-Bravo, M.J.; Mavrommatis, L.; Ehrlich, M.; Röpke, A.; Brockhaus, J.; Missler, M.; Sterneckert, J.; Schöler, H.R.; Kuhlmann, T.; et al. Astrocyte pathology in a human neural stem cell model of frontotemporal dementia caused by mutant tau protein. Sci. Rep. 2017, 7, 42991. [CrossRef] [PubMed]

152. Sidoryk-Wegrzynowicz, M.; Gerber, Y.N.; Ries, M.; Sastre, M.; Tolkovsky, A.M.; Spillantini, M.G. Astrocytes in mouse models of tauopathies acquire early deficits and lose neurosupportive functions. Acta Neuropathol. Commun. 2017, 5, 89. [CrossRef] [PubMed] 
153. Braak, H.; Braak, E. Neuropathological staging of Alzheimer-related changes. Acta Neuropathol. 1991, 82, 239-259. [CrossRef] [PubMed]

154. Braak, H.; Braak, E. Temporal sequence of Alzheimer's disease-related pathology. In Cerebral Cortex Vol. 14, Neurodegenerative and Age-Related Changes in Structure and Function of Cerebral Cortex; Peters, A., Morrison, J.H., Eds.; Kluwer Academic/Plenum Publishers: New York, NY, USA; Boston, MA, USA; Dordrecht, The Netherlands; London, UK; Moscow, Russia, 1999; pp. 475-512.

155. Duyckaerts, C.; Braak, H.; Brion, J.P.; Buée, L.; Del Tredici, K.; Goedert, M.; Halliday, G.; Neumann, M.; Spillantini, M.G.; Tolnay, M.; et al. PART is part of Alzheimer disease. Acta Neuropathol. 2015, 129, 749-756. [CrossRef] [PubMed]

156. Giaccone, G. The existence of primary age-related tauopathy suggests that not all the cases with early Braak stages of neurofibrillary pathology are Alzheimer's disease. J. Alzheimer's Dis. 2015, 48, 919-921. [CrossRef] [PubMed]

157. Ferrer, I. Defining Alzheimer as a common age-related neurodegenerative process not inevitably leading to dementia. Prog. Neurobiol. 2012, 97, 38-51. [CrossRef] [PubMed]

158. Braak, H.; Del Tredici, K. The preclinical phase of the pathological process underlying sporadic Alzheimer's disease. Brain 2015, 138, 2814-2833. [CrossRef] [PubMed]

159. Braak, H.; Thal, D.R.; Ghebremedhin, E.; Del Tredici, K. Stages of the pathologic process in Alzheimer disease: Age categories from 1 to 100 years. J. Neuropathol. Exp. Neurol. 2011, 70, 960-969. [CrossRef] [PubMed]

160. Saito, Y.; Ruberu, N.N.; Sawabe, M.; Arai, T.; Tanaka, N.; Kakuta, Y.; Yamanouchi, H.; Murayama, S. Staging of argyrophilic grains: An age-associated tauopathy. J. Neuropathol. Exp. Neurol. 2004, 63, 911-918. [CrossRef] [PubMed]

161. Nogami, A.; Yamazaki, M.; Saito, Y.; Hatsuta, H.; Sakiyama, Y.; Takao, M.; Kimura, K.; Murayama, S. Early stage of progressive supranuclear palsy: A neuropathological study of 324 consecutive autopsy cases. J. Nippon Med. Sch. 2015, 82, 266-273. [CrossRef] [PubMed]

162. Brown, J.A.; Hua, A.Y.; Trujllo, A.; Attygalle, S.; Binney, R.J.; Spina, S.; Lee, S.E.; Kramer, J.H.; Miller, B.L.; Rosen, H.J.; et al. Advancing functional disconnectivity and atrophy in progressive supranuclear palsy. Neuroimage Clin. 2017, 16, 564-574. [CrossRef] [PubMed]

163. Lewis, J.; Dickson, D.W. Propagation of tau pathology: Hypotheses, discoveries, and yet unresolved questions from experimental and human brain studies. Acta Neuropathol. 2016, 131, 27-48. [CrossRef] [PubMed]

164. Dujardin, S.; Lecolle, K.; Caillierez, R.; Begard, S.; Zommer, N.; Lachaud, C.; Carrier, S.; Dufour, N.; Aurégan, G.; Winderickx, J.; et al. Neuron-to-neuron wild-type tau protein transfer through a trans-synaptic mechanism: Relevance to sporadic tauopathies. Acta Neuropathol. Commun. 2014, 2, 14. [CrossRef] [PubMed]

165. Calafate, S.; Buist, A.; Miskiewicz, K.; Vijayan, V.; Daneels, G.; de Strooper, B.; de Wit, J.; Verstreken, P.; Moechars, D. Synaptic contacts enhance cell-to-cell tau pathology propagation. Cell Rep. 2015, 11, 1176-1183. [CrossRef] [PubMed]

166. Wang, Y.; Balaji, V.; Kaniyappan, S.; Krüger, L.; Irsen, S.; Tepper, K.; Chandupatla, R.; Maetzler, W.; Schneider, A.; Mandelkow, E.; et al. The release and trans-synaptic transmission of Tau via exosomes. Mol. Neurodegener. 2017, 12, 5. [CrossRef] [PubMed]

167. Polanco, J.C.; Scicluna, B.J.; Hill, A.F.; Gotz, J. Extracellular vesicles isolated from the brains of rTg4510 mice seed tau protein aggregation in a threshold-dependent manner. J. Biol. Chem. 2016, 291, 12445-12466. [CrossRef] [PubMed]

168. Polanco, J.C.; Li, C.; Durisic, N.; Sullivan, R.; Götz, J. Exosomes taken up by neurons hijack the endosomal pathway to spread to interconnected neurons. Acta Neuropathol. Commun. 2018, 6, 10. [CrossRef] [PubMed]

169. Tardivel, M.; Begard, S.; Bousset, L.; Dujardin, S.; Coens, A.; Melki, R.; Buée, L.; Colin, M. Tunneling nanotube (TNT)-mediated neuron-to neuron transfer of pathological tau protein assemblies. Acta Neuropathol. Commun. 2016, 4, 117. [CrossRef] [PubMed]

170. Holmes, B.B.; Diamond, M.I. Prion-like properties of tau protein: The importance of extracellular tau as a therapeutic target. J. Biol. Chem. 2014, 289, 19855-19861. [CrossRef] [PubMed]

171. Guo, J.L.; Lee, V.M. Cell-to-cell transmission of pathogenic proteins in neurodegenerative diseases. Nat. Med. 2014, 20, 130-138. [CrossRef] [PubMed]

172. Victoria, G.S.; Arkhipenko, A.; Zhu, S.; Syan, S.; Zurzolo, C. Astrocyte-to-neuron intercellular prion transfer is mediated by cell-cell contact. Sci. Rep. 2016, 6, 20762. [CrossRef] [PubMed] 
173. Clavaguera, F.; Bolmont, T.; Crowther, R.A.; Abramowski, D.; Frank, S.; Probst, A.; Fraser, G.; Stalder, A.K.; Beibel, M.; Staufenbiel, M.; et al. Transmission and spreading of tauopathy in transgenic mouse brain. Nat. Cell Biol. 2009, 11, 909-913. [CrossRef] [PubMed]

174. Clavaguera, F.; Hench, J.; Goedert, M.; Tolnay, M. Invited review: Prion-like transmission and spreading of tau pathology. Neuropathol. Appl. Neurobiol. 2015, 41, 47-58. [CrossRef] [PubMed]

175. Boluda, S.; Iba, M.; Zhang, B.; Raible, K.M.; Lee, V.M.; Trojanowski, J.Q. Differential induction and spread of tau pathology in young PS19 tau transgenic mice following intracerebral injections of pathological tau from Alzheimer's disease or corticobasal degeneration brains. Acta Neuropathol. 2015, 129, 221-237. [CrossRef] [PubMed]

176. Clavaguera, F.; Akatsu, H.; Fraser, G.; Crowther, R.A.; Frank, S.; Hench, J.; Probst, A.; Winkler, D.T.; Reichwald, J.; Staufenbiel, M.; et al. Brain homogenates from human tauopathies induce tau inclusions in mouse brain. Proc. Natl. Acad. Sci. USA 2013, 110, 9535-9540. [CrossRef] [PubMed]

177. Clavaguera, F.; Lavenir, I.; Falcon, B.; Frank, S.; Goedert, M.; Tolnay, M. “Prion-like” templated misfolding in tauopathies. Brain Pathol. 2013, 23, 342-349. [CrossRef] [PubMed]

178. Narasimhan, S.; Guo, J.L.; Changolkar, L.; Stieber, A.; McBride, J.D.; Silva, L.V.; He, Z.; Zhang, B.; Gathagan, R.J.; Trojanowski, J.Q.; et al. Pathological tau strains from human brains recapitulate the diversity of tauopathies in non-transgenic mouse brain. J. Neurosci. 2017, 37, 11406-11423. [CrossRef] [PubMed]

179. Guo, J.L.; Narasimhan, S.; Changolkar, L.; He, Z.; Stieber, A.; Zhang, B.; Gathagan, R.J.; Iba, M.; McBride, J.D.; Trojanowski, J.Q.; et al. Unique pathological tau conformers from Alzheimer's brains transmit tau pathology in nontransgenic mice. J. Exp. Med. 2016, 213, 2635-2654. [CrossRef] [PubMed]

180. Kaufman, S.K.; Sanders, D.W.; Thomas, T.L.; Ruchinskas, A.J.; Vaquer-Alicea, J.; Sharma, A.M.; Miller, T.M.; Diamond, M.I. Tau prion strains dictate patterns of cell pathology, progression rate, and regional vulnerability in vivo. Neuron 2016, 92, 796-812. [CrossRef] [PubMed]

181. Wharton, S.B.; Minett, T.; Drew, D.; Forster, G.; Matthews, F.; Brayne, C.; Ince, P.G.; MRC Cognitive Function and Ageing Neuropathology Study Group. Epidemiological pathology of tau in the ageing brain: Application of staging for neuropil threads (BrainNet Europe protocol) to the MRC cognitive function and ageing brain study. Acta Neuropathol. Commun. 2016, 4, 11. [CrossRef] [PubMed]

182. Lee, G.; Cowan, N.; Kirschner, M. The primary structure and heterogeneity of tau protein from mouse brain. Science 1988, 239, 285-288. [CrossRef] [PubMed]

183. Di Domenico, F.; Sultana, R.; Barone, E.; Perluigi, M.; Cini, C.; Mancuso, C.; Cai, J.; Pierce, W.M.; Butterfield, D.A. Quantitative proteomics analysis of phosphorylated proteins in the hippocampus of Alzheimer's disease subjects. J. Proteom. 2011, 74, 1091-1103. [CrossRef] [PubMed]

184. Zahid, S.; Oellerich, M.; Asif, A.R.; Ahmed, N. Phosphoproteome profiling of substantia nigra and cortex regions of Alzheimer's disease patients. J. Neurochem. 2012, 121, 954-963. [CrossRef] [PubMed]

185. Triplett, J.C.; Swomley, A.M.; Cai, J.; Klein, J.B.; Butterfield, D.A. Quantitative phosphoproteomic analyses of the inferior parietal lobule from three different pathological stages of Alzheimer's disease. J. Alzheimer's Dis. 2016, 49, 45-62. [CrossRef] [PubMed]

186. Muntané, G.; Dalfó, E.; Martínez, A.; Rey, M.J.; Avila, J.; Pérez, M.; Portero, M.; Pamplona, R.; Ayala, V.; Ferrer, I. Glial fibrillary acidic protein is a major target of glycoxidative and lipoxidative damage in Pick's disease. J. Neurochem. 2006, 99, 177-185.

187. Martínez, A.; Portero-Otin, M.; Pamplona, R.; Ferrer, I. Protein targets of oxidative damage in human neurodegenerative diseases with abnormal protein aggregates. Brain Pathol. 2010, 20, 281-297. [CrossRef] [PubMed]

188. Tagawa, K.; Homma, H.; Saito, A.; Fujita, K.; Chen, X.; Imoto, S.; Oka, T.; Ito, H.; Motoki, K.; Yoshida, C.; et al. Comprehensive phosphoproteome analysis unravels the core signaling network that initiates the earliest synapse pathology in preclinical Alzheimer's disease brain. Hum. Mol. Genet. 2015, 24, 540-558. [CrossRef] [PubMed]

(c) 2018 by the author. Licensee MDPI, Basel, Switzerland. This article is an open access article distributed under the terms and conditions of the Creative Commons Attribution (CC BY) license (http:/ / creativecommons.org/licenses/by/4.0/). 